\title{
(Re-) Shaping Hatred: Anti-Semitic Attitudes in Germany, 1890-2006
}

Nico Voigtländer

UCLA and NBER
Hans-Joachim Voth

ICREA,UPF, Barcelona GSE and CREi

\section{March 2012}

Abstract: In this paper, we assess the determinants of long-run persistence of local culture, and examine the success of policy interventions designed to change attitudes. We analyze anti-Semitic attitudes drawing on individual-level survey results from Germany's social value survey in 1996 and 2006. On average, we find that historical voting patterns for anti-Semitic parties between 1890 and 1933 are powerful predictors of anti-Jewish attitudes today. There is evidence that transmission takes place both vertically (parent to child) and horizontally (among peers). Policy modified German views on Jews in important ways: The cohort that grew up under the Nazi regime shows significantly higher levels of anti-Semitism. After 1945, the victorious Allies implemented denazification programs in their zones of occupation. We use differences in these policies between the occupying powers as a source of identifying variation. The US and French zones today still show high anti-Semitism, reflecting an ambitious botched attempt at denazification. In contrast, the British and Soviet zones, register much lower levels of Jew-hatred. 


\section{Introduction}

When and why do people change their mind? And how much can policy modify beliefs and attitudes? Attitudes can remain unchanged for long periods of time, and be passed on from parents to children even in a different environment (Nunn and Wantchekon 2011; Guiso, Sapienza, Zingales 2008; Fernandez and Fogli 2009), or they can change radically within a generation or two (Fernandez-Villaverde and Greenwood 2011). The causes for change are typically hard to pin down: Policies and economic incentives interact with cultural preferences in complex ways (Tabellini 2008; Doepke and Zilibotti 2008; Bisin and Verdier 2000).

In this paper, we first document how powerful the past's grip on present-day attitudes is German municipalities that voted strongly for anti-Semitic parties between 1890 and 1933 are still home to many more individuals with negative views of Jews. This is remarkable given the scale of social, cultural, demographic, and economic change in Germany after 1945. We demonstrate that mass migration weakened persistence, while both horizontal transmission peer effects - and vertical transmission - parent to child - are important in perpetuating beliefs at the local level. Policy modified attitudes, both in the transition from (democratic) Weimar Germany to Nazi rule, and after 1945. Cohorts growing up under the Nazi regime are much more anti-Semitic than those born before or after. Finally, we look at the attempted reeducation of Germans after 1945. Allied policy during the war established denazification as a priority for the time after victory. We examine when these policies were successful, and when they failed.

Germany's persecution of European Jewry is one of the defining moments of world history. After 1945, Germany witnessed one of the largest efforts to re-educate an entire population in history, aiming to stamp out racial hatred, authoritarianism, and militarism (Biddiscombe 2007). The occupying forces took over the administration of Germany, ran and licensed all newspapers and other media, revamped school curricula, and incarcerated hundreds of thousands of citizens who had been involved with the Nazi regime possible. Millions of Germans had to submit detailed questionnaires and were tried in Allied courts; hundreds of thousands were dismissed or imprisoned. Anti-Semitism changed from an officially sanctioned principle of policy to a public taboo; citizens were forced to visit former concentration camps and attend films depicting the horrors of the Holocaust.

What is unclear is if this massive exercise in re-education has succeeded or failed in transforming German attitudes over the long run. Germans after the war liked to think that 1945 was equivalent to their nation's "zero hour," implying that the slate had been wiped 
clean. At the same time, there was continuity at many levels: "In Bavaria in 1951, 94 percent of judges and prosecutors, 77 percent of finance ministry employees and 60 percent of civil servants in the regional Agriculture Ministry were ex-Nazis" (Judt 2005). Sixty percent of reconstituted West German diplomatic corps had served in the SS or the Gestapo. More than a third of Germans in the 1950s felt that Germany should not have Jews living in its borders, and a quarter held Adolf Hitler in high regard. Even today, opinion polls regularly find that a significant share of the German population holds anti-Semitic views (Bergmann and Erb 1997).

We start from the assumption that, in the absence of major shocks, local beliefs largely remain constant over time. This hypothesis is motivated by insights from modern evolutionary biology: Cultural transmission - the unexamined adoption of beliefs from parents, peers, and neighbors - can be a superior strategy for human communities. This is particularly true if the environment remains largely unchanged (Boyd and Richerson 1985, 1995). Both parental investment in forming their offspring's attitudes and peer effects can create hysteresis in attitudes.

In this study, we focus on the local persistence of anti-Semitic attitudes, using individual returns from the German social survey (GESIS). We correlate these with voting behavior in the same location between 1890 and 1933. There is strong persistence overall - individuals polled in 1996 and 2006 were more likely to show negative attitudes towards Jews if people in the same town or city voted for one of the anti-Semitic parties in the 1890 s, for the nascent Nazi party in 1924/28, or if they supported the NSDAP in the 1930s.

We aggregate votes for the anti-Semitic parties during the Empire before WWI, and for the Nazis into a single indicator (Allvote). Next, we stratify our sample of modern-day responses into terciles of historical anti-Semitic voting patterns. ${ }^{1}$ Table 1 shows the pattern that emerges. All of our three indicators for historical anti-Semitism move hand-in-hand with Allvote. Nazi party support in the 1920s, for example, goes from an average of 1.8 percent to 9.4 percent between the first and third tercile of Allvote. Anti-Semitic parties in the late Empire before 1914 received 3.6 percent instead of 0.8 percent. Crucially, responses to questions designed to capture anti-Semitism in 1996 and 2006 are significantly different, depending on the tercile of Allvote. Where anti-Semitic parties were particularly successful, Germans today on average feel that Jews have too much influence, that they do not want them as neighbors or family members, that Jews are responsible for their own persecution, and that they should not have equal rights. ${ }^{2}$

\section{[insert Table 1 here]}

\footnotetext{
${ }^{1}$ We standardize individual election-year results and then sum them for all elections.

2 The summary measures at the bottom of Table 1 are explained in section III.
} 
Places in Germany with a tradition of anti-Semitism are not just more anti-Semitic today they are generally more xenophobic. Nonetheless, as we show in the econometric analysis, the hatred of Jews does not simply reflect a strong dislike of ethnic minorities. We find that a municipality's past matters for modern-day anti-Jewish attitudes even if we control for the overall level of xenophobia shown by the individual. Nor is anti-Semitism simply a reflection of right-wing attitudes, or the result of economic deprivation. Our results apply equally to the Western and Eastern part of the country.

We also investigate in detail what influences the transmission of anti-Semitic attitudes. Many models of cultural transmission emphasize the importance of parent-child interaction (Bisin and Verdier 2000; Tabellini 2008; Doepke and Zilibotti 2008); as Fernandez and Fogli (2009) show, "vertical" transmission can be powerful even in a completely new environment. We examine the importance of this channel, and compare it with peer effects. Germans from families where everyone agrees on the subject of "foreigners" are also more likely to show attitudes correlated with voting behavior in the distant past. The same is true for attitudes amongst friends - places where individual survey responses indicate more conformism also show more persistence. The reason for this can be investigated by analyzing the attitudes of second-generation immigrants. Where their views converge towards those of their German neighbors, persistence of anti-Semitism is also significant; and where it is weak, persistence is markedly lower. This suggests that vertical transmission among peers plays an important role in the persistence of local culture.

After 1945, Germany experienced one of the largest population movements in history. Millions of ethnic Germans fled the Red Army (Buchardi and Hassan 2011). They were allocated to towns and cities based on the stock of undestroyed housing available. We document that where areas received many expellees from the East, transmission today is markedly weaker. This suggests that massive shocks to population composition can weaken the grip of history on present-day attitudes.

The Nazi regime was engaged in one of the most comprehensive propaganda efforts in history. It controlled all media and the arts, and put the regime's stamp on schools, universities, films and on the radio. Anti-Semitism was one of the central tenets of Nazi ideology. We investigate if and when this indoctrination was successful. Germans born between 1920 and 1939 were exposed to Nazi indoctrination during their most impressionable years. They are still more anti-Semitic today than cohorts born either before or after. However, this effect is much less pronounced for Germans who grew up under the Nazis, but in areas with substantial electoral support for left-wing parties.

Finally, we investigate the effects of denazification policies. These differed significantly by Allied zone of occupation after 1945. Areas under British and Soviet control show markedly 
less anti-Semitism today. In contrast, the American and French zones have the highest levels. This is true even after controlling for differences in historical voting patterns. We relate the reduction in anti-Semitism in some zones of occupation to differences in denazification. Where the Allies focused on major perpetrators and carried out denazification with relative (perceived) fairness, anti-Semitism is lower than we would predict based on historical voting patterns; where it was carried out in a heavy-handed fashion, investigating and penalizing large parts of the population, it created massive resentment, and the anti-Semitism remains relatively strong, even after controlling for earlier Jew-hatred..

This paper is part of a larger research project. In a companion paper (Voigtländer and Voth 2012), we investigate the medieval roots of $20^{\text {th }}$ century anti-Semitism. There, we demonstrate that in a cross-section of over 300 towns and cities, anti-Semitic acts and attitudes in Germany between 1920 and 1945 are significantly correlated with medieval pogroms. The probability of pogroms, of votes for the Nazi party, anti-Semitic letters, deportations, and attacks on synagogues can all be predicted by persecutions of Jews during the Black Death. The persistence of similar behavior towards the same ethnic minority over more than half a millennium is a striking fact. It begs the question if the views and preferences of modern-day Germans still reflect past attitudes.

Research on modern-day anti-Semitism in Germany has already shed some light on the role of the past, and on factors influencing transmission. Based on self-reported survey returns, for example, Frindte, Funke and Jacob (1999) find that right-wing Germans have twice as many grand-parents who were members of the Nazi Party or the SS. ${ }^{3}$ Young East Germans are more critical of the GDR if their parents were opposed to the regime; the extent of intergenerational transmission depends on the quality of parent-child relationships. Our paper also relates to a growing literature on the historical causes and effects of the Holocaust, and of the effects of World War II. Acemoglu et al. (2010) show that parts of Russia occupied by the Germans - where the majority of Jews died - experienced slower city-growth, and still have a greater proclivity to vote for the Communist Party. Grosfeld et al. (2011) argue that the extermination of Jews in the pale of settlement in Eastern Europe has contributed to a persistent anti-market culture. Peer effects during the Nazi period have been investigated by Waldinger (2010, 2012), who finds that the purge of German universities after 1933 lowered the quality of research amongst PhD students. Akbulut-Yuksel and Yuksel (2011) argue that expelling Jewish school teachers had major effects on the educational accomplishments of German students after the Nazi takeover.

Our research is connected with work on the determinants and consequences of cultural differences. Nunn (2008) shows that areas in Africa affected by the slave trade are poorer

\footnotetext{
${ }^{3}$ Similar self-reported results can be found in Noelle-Neumann and Ring (1984).
} 
today; Nunn and Watchekon (2011) conclude that the effect is driven by lower levels of trust. Alesina, Giuliano and Nunn (2011) examine the impact of agricultural techniques on gender attitudes, and find that areas historically more suitable to the plough score systematically lower on measures of gender equality today. Papers taking an epistemological approach use attitudes amongst the children of immigrants to the US to measure the intergenerational transmission of culture. Fernandez and Fogli (2009) show that fertility behavior of US immigrants' children still reflects attitudes in their parents' place of birth; Algan and Cahuc (2010) demonstrate that inherited trust of second-generation Americans has predictive power for economic growth in ancestors' countries of origin. Jha (2008) argues that Indian cities with a history of co-operation between Hindus and Muslims are much less prone to violence today. Guiso, Sapienza and Zingales (2008) find that Italian cities that were self-governing in the middle ages are today richer, and show higher levels of social capital. Tabellini (2010) finds that historical cultural attributes are better predictors of economic performance over the long run than institutions.

On the theory side, our research is related to important work by Bisin and Verdier (2000, 2001). They assume 'imperfect empathy,' with parents choosing preferences for children that will both make them more similar to themselves and equip them to prosper. They show that with plausible preference parameters, initially heterogeneous populations will only intermarry to a limited extent. Tabellini (2008) instead presents a model of cooperation in which parents invest in their offspring's preferences to optimize their prospects. Acemoglu and Jackson (2011) analyze how historically evolved norms of co-operation can change as a result of prominent agents taking the lead.

Relative to the existing literature, our contribution is threefold. First, in contrast to studies using self-reported data on friends and family with a Nazi past, we use local variation in past voting patterns as a source of identification. This allows us to avoid the obvious potential for bias in self-reporting. Second, we document the strong regional persistence of an attitude that is heavily discouraged. Official policy banning hate speech, Holocaust-denial and extensive revisions of textbooks have not been able to eradicate the transmission of racial hatred. Third, we show under which conditions cultural norms persists, and when they are malleable. Indoctrination under Hitler worked best for cohorts with maximum exposure to Nazi ideology. Persistence is lowest in the British occupation zone, which witnessed relatively 'fair' and pragmatic denazification efforts, targeted at major perpetrators. Across age groups, there are no significant differences. The predictive power of historical voting patterns is broadly the same for individuals born after 1950 as for those born in $1910 .^{4}$

\footnotetext{
${ }^{4}$ The mean coefficient on past anti-Semitism is actually higher, but the difference is not statistically significant.
} 
The paper proceeds as follows: Section II provides an overview of the history of antiSemitism on German territory and the rise of anti-Semitic parties in the late $19^{\text {th }}$ and early $20^{\text {th }}$ century. We also discuss indoctrination under the Nazi regime and Allied denazification policies after WWII. Section III presents our data and Section IV the main empirical results. Section V analyzes the issue of malleability. Robustness checks and issues related to interpretation are summarized in Section VI. Section VII concludes.

\section{Background and Context}

In this section, we briefly summarize the history of anti-Semitism in Germany during three periods - the late Empire, the interwar years, and the period after the end of World War II. For the present, we survey existing studies on attitudes towards Jews.

Jews first settled on German territory in the late medieval period. By the $11^{\text {th }}$ century, more than 1 million Jews had settled in Western Europe. Starting with the First Crusade in 1096, a wave of pogroms during the late medieval period destroyed the rich fabric of Jewish communities (Haverkamp 2002, Toch 2003). By the $16^{\text {th }}$ century, most larger cities no longer had Jewish communities; while some survivors of pogroms migrated East, others lived in smaller villages. From the $17^{\text {th }}$ century onwards, Jews were allowed to settle in larger towns and cities to a limited extent. Restrictions on Jewish life were extensive, with quotas for the total living in a city, for the total number of married couples allowed, etc. (Katz 1980).

During the French occupation of large parts of Germany in the early $19^{\text {th }}$ century, Jews were given equal rights; as soon as the French troops left, the emancipation of the Jews was reversed in many places. Mobs attacked Jews in various localities after the French withdrawal - a wave of riots and pogroms, the so-called "Hep-Hep-Riots" swept through Germany (Katz 1994).

\section{II.A. Imperial Germany}

Anti-Semitic agitation soon took off at the national level after the founding of the German Empire in 1871. By 1880/81, a nation-wide petition collected more than 250,000 signatures. Amongst the signatories were many leading scientists, writers, clergymen and officers. The petition urged the government to restrict the immigration of Jews, and to exclude them from the army, the law courts, and from school instruction and university teaching. The government under Chancellor Bismarck ignored the petition.

A large number of anti-Semitic parties were formed in the late $19^{\text {th }}$ century. While the members of some mainstream parties espoused anti-Semitic views, these parties were focused on the implementation of anti-Jewish policy as their main aim. By the 1890 s, these parties put 
forward candidates in elections for the Reichstag, the German parliament. While never a significant force at the national level, there was considerable variation at the local level. In some districts, as many as $65-75 \%$ of votes would be cast for the anti-Semitic parties. In 1893, for example, in $10 \%$ of all districts, the anti-Semites polled more than a tenth of the vote (Wawrzinek 1927).

In the late Imperial period, the influence of anti-Semitic parties declined. Focused on a single issue and without influence on national policy, voters started to turn away.

\section{II.B. Weimar period}

World War I saw a major resurgence of anti-Semitism. During the war, Jews were blamed for food shortages and involvement in the black market. The army ordered a census of all Jewish personnel, allegedly to counter claims that few German Jews served in front-line positions. It never published the results.

With the war lost, many right-wing politicians started to blame Jews, pacifists, and socialists. The leading role of Jewish politicians in the revolution of 1918 fanned the flames of antiSemitic sentiment. Demobilized army units (Freikorps), drafted by the new Republican government to fight a left-wing insurgency, were often hives of anti-Semitic sentiment. With the descent into hyperinflation after 1920, the social and economic situation grew markedly worse. A large number of political parties campaigned with an anti-Semitic agenda (Striesow 1981). Of these the most radical was the German National Socialist Worker's Paper (NSDAP). It staged an attempted putsch in Munich in 1923, which collapsed after an armed confrontation with the police. Banned from participating in elections, the NSDAP used a proxy party, the DVFP (with which it later merged) to put candidates forward in 1924; from 1928 , it contested in national elections.

Anti-Semitic violence took a variety of forms. Freikorps soldiers murdered Rosa Luxembourg, the leader of an ultra-left attempted revolution in 1918, and Walter Rathenau, foreign minister of Germany in 1922. There were also pogroms, hate-speeches and desecrations of Jewish cemeteries in the 1920s. Most student organizations at German universities had become heavily anti-Semitic by the 1920 s.

After its failed putsch, the NSDAP decided to seek power by legal means. It toned down the more radical parts of its agenda after 1928 (Stachura 1978, Heilbronner 2004). While antiSemitism never disappeared from the party's program, it became less prominent as the Great Depression led a whole new group of disaffected voters to the NSDAP. During the final years of the Weimar Republic, the violence unleashed by storm troopers was directed against the Communists, the Social Democrats, the police forces of the democratic state, as well as Jewish shopkeepers, synagogues, and cemeteries (Walter 1999). 
The extent of racial hatred at the core of national socialism only became fully visible after 1933. Starting with boycotts of Jewish establishments and the exclusion of Jewish civil servants and doctors, persecutions grew more comprehensive and vicious. As the German sphere of influence expanded after 1939, these policies eventually culminated in systematic genocide in the extermination camps of Eastern Europe.

\section{II.C. Indoctrination after 1933}

The Nazi regime engaged in high-profile, public discrimination of Jews from its inception. In February 1933, the SA attacked Jewish-owned shops, medical and dental offices, and department stores, often with the connivance of the police. In early April, the Nazi regime organized an official boycott of Jewish shops. Jews working in law courts were often physically attacked as early as March; in April, all Jews were excluded from the civil service. Soon thereafter, they were also stopped from practicing as lawyers or doctors (Kaplan 1999).

In the following years, persecutions accelerated. With the so-called Nuremberg laws of 1935, Jews were classified according to the number of Jewish grandparents, with an escalating scale of legal discriminations for those deemed more Jewish. The majority of German Jews emigrated in response to unprecedented discrimination, losing most of their property as a result of punitive taxes on emigrants. Pre-war persecution culminated in the so-called "Reichskristallnacht" (Night of Broken Glass) in 1938. It saw attacks on synagogues and Jewish property all over the Reich. The first larger-scale deportations in 1938 were followed by wave upon wave of transports to the East after 1941, mostly to extermination camps (Longerich 2010).

The Nazi regime made an unprecedented effort to control and influence the beliefs and feelings of the population. ${ }^{5}$ The Propaganda Ministry under Josef Goebbels controlled all art and the media, from newspapers, music to sculpture, painting, books, film and the radio (Kershaw 1983; Welch 1983). It is widely considered to have produced a quantum leap in the quality and effectiveness of indoctrination, disseminating Nazi ideology through a range of measures, from pure propaganda films to subtle messages embedded in romantic films and news paper columns. ${ }^{6}$ Children and teenagers were particularly targeted, both through the new school curricula and by being drafted first into the various NS youth organizations. ${ }^{7}$ As one contemporary describes the experience: "We who were born into Nazism never had a

\footnotetext{
${ }^{5}$ The only other country with a similarly consistent commitment to propaganda and indoctrination was Soviet Russia.

${ }^{6}$ Not all of these were equally successful. For example, while "Jud Süß" (an anti-Semitic film about an 18C Jewish financier) was a box office hit, the crass "Der Ewige Jude" (The Eternal Jew) was a failure.

${ }^{7}$ These included, first, the Jungvolk (from age 10 to 14) and then the "Hitlerjugend" (Hitler Youth) or "Bund Deutscher Mädchen" (Association of German Girls). In 1933, all other youth organizations were banned; by 1936, membership was compulsory for all Aryans. The Official Handbook for Schooling the Hitler Youth (Brennecke 1938) devotes fully 45 out of 105 pages to racial ideology.
} 
chance unless our parents were brave enough to resist the tide and transmit their opposition to their children. There were few of those." (Heck 1988).

\section{II.D. Anti-Semitism and Denazification after 1945}

At the Potsdam conference in 1945, the Allies decided to purge Nazi Party members from public life, and replace them by "persons who, by their political and moral qualities, are deemed capable of assisting in developing genuine democratic institutions in Germany."8 Attitudes towards Jews took center stage in efforts to re-educate Germans after 1945. Denazification was not a single policy, but a set of different practices. In each zone of occupation, implementation differed. When the denazification program came to an end, millions of cases had been processed; some two million Germans were punished (Biddiscombe 2007).

In the American zone, the denazification program was comprehensive and highly punitive in total, a quarter of the population living under American occupation was affected (Teschke 2001). Those suspected of major crimes were placed in camps; members of the Nazi party and other prohibited organizations were summarily dismissed from office, depending on their rank. Soon, the need for specialists to organize reconstruction took precedence over denazification. By 1946, much of the process was transferred to German control. Many suspects that had previously been judged too incriminated to be employed by the American occupying forces were now classified as Mitläufer (fellow travelers), with no punishment. By 1948, more than 80 percent of civil servants dismissed by the military government had been reinstated (Herz 1948). Initial German enthusiasm for the process quickly gave way to scepticism amid complaints about unfairness. In the American zone, German support for denazification dropped from 57 percent in 1946 to 17 by 1949. In some areas, there was no co-operation with the process whatsoever. In the rural Bavarian community of Wolfratshausen, where 8,000 of the 40,000 inhabitants had been Nazi party members, the conservative Landrat (district head) and his associate stamped every single questionnaire with the words "nothing prejudicial known" ("nichts Nachteiliges bekannt," Bidisscombe 2007).

As part of the attempt to re-educate the public, many Germans of all ages in the US zone of occupation were forced to visit concentration camps, or to attend public viewings of films showing the horrors of the Holocaust. Contemporaries recall that they could be made to attend, but not to watch or engage (Judt 2005). Of all the denazification processes in the different zones of occupation, the American one was the most intrusive. Its size and structure led to perceived unfairness. In 1945, "conditions were still relatively propitious for a swift

\footnotetext{
${ }^{8}$ Agreements of the Berlin Conference, Section IIA, Paragraph 6.
} 
and radical operation." Thereafter, practical concerns and social pressure slowed the process (Herz 1948). The initial purge was comprehensive but highly mechanical; its scope did not allow for enough evaluation of individual cases. Many important Nazis escaped punishment altogether since the most important cases were left for last; perpetrators of smaller crimes were often punished quickly and severely.

Konrad Adenauer, who later became the first Chancellor of West Germany, argued publicly in 1946 that denazification in the US zone was counter-productive: “... because Nazism did have such deep roots in his country, [he] thought it more prudent to allow and even encourage silence on the subject" (Judt 2005). In the eyes of many, American denazification resulted in over-ambitious "bureaucratic quagmire" (Vogt 2000), which had the most negative image of all programs. The Jewish Adviser to the American Military Governor, Rabbi Philip Bernstein, summed up the program's success when he said in $1947::^{9}$ “ ... if the United States Army were to withdraw tomorrow, there would be pogroms on the following day."

The Soviet zone of occupation took a somewhat different approach. It was primarily concerned with establishing Communist administrative control. Denazification was secondary. The Soviet military authorities dismissed large numbers of Nazi members from administrative positions in 1945, but encouraged party members without major crimes on their record to join the Communists. National Socialism was seen more as a reflection of economic and social conditions, not of racism. In general, the Soviet approach is considered "relatively tough denazification" (Biddiscombe 2007). The process had some degree of legitimacy because high-ranking, tainted officials, especially judges, were removed thoroughly; communists tended to cooperate with denazification. At the same time, the harsh behavior of Soviet troops towards civilians in 1945 undermined the population's support for policies of the occupying power, and it was considered by many as a form of victor's justice.

The British Control Commission for Germany (CCG) considered the American approach of mass arrests and massive re-education as impractical and counter-productive (Teschke 2001). The British focused on removing powerful Nazi party members, minimizing dismissals in a bid to balance practicality and justice. By 1946, the British turned the process over to German denazification panels. These processed 2 million questionnaires (in a population of 22 million). Judgments became milder the more control was ceded to lower-level German institutions (Spruchkammern). While some historians have been sceptical of the British approach, it bred less resentment than the American one - in 1946, the German public generally urged greater rigor and comprehensiveness (Turner 1989). This shows the

\footnotetext{
${ }^{9}$ Cited in Goschler (1991).
} 
pragmatic and limited nature of British efforts at denazification, as well as the significant public support the program enjoyed.

The Federal Republic of Germany granted amnesties to most party members and officials involved in the Nazi state before 1945, except for the most serious offenders. There were many continuities - the lawyer who had written the commentary on the Nuremberg racial laws, Hans Globke, was employed as chief of staff in the West German Chancellery. The judiciary, universities, foreign office, and (after their refounding) the West German armed forces were heavily staffed by party members, SS-members, high ranking Wehrmacht officers, and those implicated in the planning and execution of Nazi policies. After the student demonstrations in 1968, the trial of Adolf Eichmann, and the German Auschwitz Trial, there was greater public concern in Germany over the influence of incriminated officials. The statute of limitations was extended repeatedly to avoid letting all perpetrators of crimes before 1945 escape scot-free. As late as the 1990s, there were hundreds of investigations still on-going - not necessarily a sign that they had been vigorously pursued in the first place.

The overall effects of denazification have been difficult to assess. The American military government immediately began conducting surveys, and estimated in 1946 that almost 40\% of Germans were anti-Semites; of these, close to half were labelled "hard-core." A study in 1948 found similar values (Bergmann and Erb 1997). German surveys in the early 1950s also put the proportion of anti-Semites at approximately a third of the population. Later studies found similar proportions all the way into the 1970s (Silbermann 1982). By 1989, in West-Germany, one survey classified only $46 \%$ of the population as not anti-Semitic, and put the proportion of those with extreme or significant negative views of Jews at $14 \%$ (Emnid 1989).

Comparative studies of Germany, England and France in the 1960s suggested that antiJewish views were held by similar proportions of the population in each country (Panahi 1980). After 1989, it became possible to conduct surveys in East Germany. Contrary to some expectations, East Germans were actually less anti-Semitic than their Western countrymen. Comparative studies put the proportion with strongly negative views of Jews at between a third and half of Western values (Bergmann and Erb 1997).

The 1980s saw an increasing tendency to discuss the need for Schlußstrich - drawing a line under discussion of the past and Germany's historical guilt for the Holocaust. Historians debated the extent to which it was possible for Germany to develop a normal relationship with its past in the so-called Historikerstreit (Wehler 1988, Nolte 1987). At the same time, the policy of supporting Israel (with both money and armaments) has not been questioned since it was instituted in the 1950s. 
With the fall of the Berlin Wall, public attention has focused on anti-democratic and violent tendencies in the former East. Neo-Nazi violence against foreigners is a particular concern. Many observers blame right-wing radicalism in the former GDR on a lack of awareness about the past before 1945 in the East. Overall, radical right-wing parties have had only limited success in post-war Germany. In the late 1960s, the NPD (Nationaldemokratische ParteiNational Democratic Party) won seats in regional elections; it never reached the required 5\% of the vote in federal elections (Bromba and Edelstein 2001). Since 2004, it is represented in the Saxon diet, and receives a measure of support in most areas of East Germany. In 2011, new information revealed that a string of murders in Germany since 2000 had been perpetrated by a terror group called Nationalsozialistischer Untergrund (National Socialist Underground). Several of those implicated in these crimes were close to the NPD.

\section{Data}

\section{III.A. ALLBUS Survey Data: Individual-Level Indicators for Anti-Semitism}

The German Social Science Survey (ALLBUS) is conducted every two years. Starting in 1980, a representative sample of residents in Germany is asked a wide array of questions. These range from schooling and the attitude towards divorce, to income, migratory background, attitudes towards education and the government, to the use of condoms. Responses to the questions of interest for this study are generally made available without regional identifiers, to avoid confidentiality issues. For public use, ALLBUS data are compiled at the level of Regierungsbezirk (prefecture). While data are collected at the local level, this disaggregate information is not publicly available. However, the ALLBUS research staff kindly allowed us to access the detailed data at their facility, so that we can run our analyses at the local level, for altogether 264 cities with relevant data.

In two surveys (1996 and 2006), respondents were asked four main questions that examine anti-Semitic attitudes. The questions ask about agreement or disagreement with each of the following statements (on a scale from 1-7):

- Influence: "Jews have too much influence in the world."

- Shame: "I am ashamed of all the crimes that Germans have committed against Jews"

- Exploit: "Jews are exploiting the history of the Third Reich for their own advantage, and try to make the Germans pay for it."

- Responsible: "Jews are partly responsible for their persecution because of their behavior." 
In addition, the survey includes three questions about Jews that are also asked about other minorities (Turks, asylum-seekers, Italians, Germans who immigrated from Eastern Europe): ${ }^{10}$

- Neighbor: "How agreeable or disagreeable would it be for you to have a Jewish neighbor?"

- Marriage: "How agreeable or disagreeable would it be for you if a Jew married into your family?"

- Rights: "Jews living in Germany should have equal rights as Germans in all respects."

In total, some 2,500-3,000 respondents answered these questions in each survey year. We combine the set of responses from 1996 and 2006 to construct our main dataset. For ease of exposition, we code each of the seven variables explained above such that higher values indicate more anti-Semitic attitudes.

Table 2 shows the partial correlation across these variables at the individual level (obtained at the GESIS facility in Mannheim/Germany). All variables are significantly correlated with each other, with the expected positive sign. Coefficients range from .14 to .65.

\section{[insert Table 2 here]}

There is also rich regional variation in the data at the prefecture level. Figure 1 shows the percentage of people who agreed with the statement that "Jews have too much influence in the world" (score of 5 or higher on a scale from 1-7). Responses vary significantly across prefectures. For example, only $14 \%$ of respondents in Brandenburg agreed. At the other end of the spectrum, $77 \%$ of people surveyed in Upper Franconia (Oberfranken) felt that way - a concentration of extreme attitudes more than 5-times higher than in Brandenburg. Other questions show a similarly high dispersion of beliefs. While there is a conspicuous concentration of pockets recording high levels of anti-Jewish sentiment in the South of the country, the overall impression is one of a broad geographic spread. Areas where many Germans responded by saying that Jews had too much influence, or that they brought the Holocaust upon themselves, often lie side-by-side with other areas where such sentiments are rare.

\section{[insert Figure 1 here]}

We construct two measures of present-day anti-Semitism in Germany. First, $A S^{\text {broad }}$, is the individual-level average of all variables shown in Table $2 .{ }^{11}$ This measure reflects broad anti-

\footnotetext{
${ }^{10}$ There is also a fourth question in this category: "How strongly does the lifestyle of Jews living in Germany differ from that of Germans?" For this question (but not for the others), possible answers include "I don't know" or "no response." Because $20 \%$ of respondents fall into this category, we do not use this question for our main analysis to avoid the loss of observations when deriving the average across all variables with a 1-7 scale.

${ }^{11}$ Because all variables in Table 2 are measured at a 1-7 scale, the average provides a simple and consistent combined measure. In line with the literature, we do not use Shame (Bergman and Erb 2000; Lüdemann 2000).
} 
Semitism. Second, we construct a more narrow measure that indicates committed antiSemitism: $A S^{\text {comm }}$ is the proportion of people for whom all variables Influence, Exploit, and Responsible are at least 6 (on a scale of 7). ${ }^{12}$ Some 5 percent of the respondents in our survey (288 individuals) qualify as committed anti-Semites in our dataset. ${ }^{13}$

There is also considerable consistency in responses at the regional level. In Table 3 we show average responses for the main survey question for the two prefectures with the lowest and the highest score of $A S^{\text {broad }}$ (Mittelfranken and Hamburg vs. Rheinhessen and Niederbayern). We also explore an auxiliary survey question for each prefecture, asking whether "one should draw a line beneath Germany's Nazi past." ${ }^{\text {"14 }}$ Respondents in Hamburg overwhelmingly felt that Jews deserved equal rights, that they would be welcome as neighbors and family members, and that they do not have too much influence in the world. Only 25 percent of Hamburg citizens felt that Germans should stop engaging with the country's Nazi past, and less than 6 percent qualify as committed anti-Semites. In contrast, survey participants in Niederbayern were much less welcoming toward Jews as neighbors and family members, and believed Jews had too much influence and exploited their victim status. Fully 86 percent wanted a final line drawn under Germany's history between 1933 and 1945; 16.4 percent qualify as committed anti-Semites.

\section{[insert Table 3 here]}

\section{III.B. Measures for $19^{\text {th }}$ and Early $20^{\text {th }}$-Century Anti-Semitism}

We combine indicators of anti-Semitism from the late $19^{\text {th }}$ and early $20^{\text {th }}$ century with the ALLBUS survey data. Our historical data are derived from votes for anti-Semitic parties between 1890-1912, and from votes for the Nazi party in the 1920s. Anti-Semitism revived after the founding of the Reich in 1871 and peaked in the late $19^{\text {th }}$ century. In the six nationwide elections between 1890 and 1912, several parties focused on anti-Semitism as the principal political message and put forward candidates in a varying number of districts. They competed for seats in 31 to 101 out of the 264 electoral districts in our sample. There was substantial regional variation - from less than $0.1 \%$ of votes received to more than $70 \%$ in extreme cases. We use the average vote share from all six elections, ASVOTE ${ }^{19 C}$, as our first indicator for historical anti-Semitism. ${ }^{15}$

\footnotetext{
12

13 Unsurprisingly, the two measures are closely related: individuals with AScomm $=1$ have a measure of ASbroad $=5.3$, versus ASbroad $=3.1$ for the remainder.

${ }^{14}$ This relates closely to the question debated in the Historikerstreit. While not a sign of anti-Semitism, those who respond in the affirmative tend to hold markedly more right-wing views in general.

${ }^{15}$ We drop observations for cities where no anti-Semitic parties ran during any of the six elections (i.e., where ASVOTE $\left.^{19 C}=0\right)$. The reasons is that we do not know if the absence of a candidate reflects local sentiment - or simply made it impossible to be expressed. We therefore expect more noise in a sample that includes these districts. Our results are robust to using all cities, assuming that anti-Semitic parties would have received zero
} 
As our second indicator for historical anti-Semitism, we use Nazi party votes from the 1920s. This arguably reflects committed anti-Semitic sentiment at the local level -- the Nazi party emphasized its heavily anti-Jewish program during its early years. It is only after 1928 that the party switched electoral tactics (see section II). After the Beer Hall putsch in 1923, the Nazi party was banned for several years, and the DVFP (Deutsch-Völkische Freiheitspartei) attracted much of its vote in the May 1924 election. ${ }^{16}$ The variable NSVOTE $^{20 s}$ is the average vote share of the DVFP in the May 1924 election and the NSDAP vote share in the May 1928 election. Our third measure reflects local support for the Nazi party after 1928, when it focused on attracting disaffected protest voters (while never disavowing its anti-Semitic origins). NSVOTE ${ }^{30 s}$ is the average vote share for the NSDAP in the September 1930 and the March 1933 election. ${ }^{17}$ This variable proxies for mostly broader, less radical anti-Semitic sentiments, combined with generally anti-democratic views. ${ }^{18}$

Finally, we derive the variable ALLVOTE as the average of the previous three indicators. Because NSDAP vote shares in the 1930s were substantially larger than the earlier NSVOTE $^{20 s}$ or ASVOTE ${ }^{19 C}$, we standardize the three components before calculating their average. In this way, we avoid that the high NSVOTE $^{30 s}$ dominates the remaining variables.

In Table 1, we group the sample into terciles of $A L L V O T E$ and report the corresponding conditional averages for our outcome variables. Both broad and committed anti-Semitism today are more pronounced in cities with a history of anti-Semitic election behavior: $A S^{\text {broad }}$ increases with each tercile of ALLVOTE, and is .17 standard deviations higher in towns and cities in the highest tercile of ALLVOTE as compared to the lowest tercile. A similar observation holds for the share of committed anti-Semites, with consistently extreme views on Jews. $A S^{c o m m}$ is $50 \%$ (or 2 percentage points) higher in towns with the highest historical vote shares for anti-Semitic parties. Xenophobia is also more rampant in cities with higher ALLVOTE, but here the increase is not linear. We also see that the individual components within the principal component measure $A S^{\text {broad }}$ confirm the aggregate results: each questionnaire item is monotonically rising as we move from one tercile to the next.

votes where they did not list candidates. This is a reasonable assumption, given that the 10th percentile of vote shares - for cities where the party ran - is $0.3 \%$ on average across the six elections.

${ }^{16}$ Across the more than 4,500 German election districts in the original election data, we find a correlation of .51 between the voting results of the DVFP in 1924 and the Nazi Party in 1928, significant at the 1\% level. The DVFP and NSDAP merged later.

${ }^{17}$ There were also federal elections in July and November 1932. However, for these data are not available at the municipality level.

${ }^{18}$ This is not to say that committed anti-Semites did not vote for the Nazi party in the 1930s. However, their share in the overall NSDAP vote was likely small when it won 18 and 44 percent of the popular vote in 1930 and 1933, respectively. 


\section{III.C. Covariates and Control Variables}

We begin by describing the construction of an important control variable that we will use below to distinguish anti-Semitic sentiment from general xenophobia. We construct the variable $X E N O$ as the first principal component of the response to seven questions about the attitude towards foreigners: ${ }^{19}$

- "Immigration of non-European workers should be restricted/prohibited"

- "Foreigners enrich our culture"

- "Foreigners steal our jobs"

- "Foreigners commit crimes more frequently"

- "Naturalization of foreigners: Only if of German descent"

- "How agreeable or disagreeable would it be for you if a foreigner married into your family?"

- "Is it okay if the local pub owner discriminates against foreigners?"

All factor loadings have the expected sign. We standardize the variable XENO to obtain beta coefficients. Next, we derive a variable for the right-wing political attitude. ALLBUS asked subjects to position themselves on a scale from 1 to 10 , where 1 is extreme left, and 10 extreme right. For values larger or equal to 8, we define the dummy Rightwing; there are 633 individuals that fall into this category. The dummy High School equals 1 if the subject finished the German 'Gymnasium,' altogether 12-13 years of schooling. University takes on the value 1 if an individual finished college, received a master's degree or a $\mathrm{PhD}$. We also control for age and age ${ }^{2}$ of individuals at the time of the survey (1996 or 2006). All control variables mentioned thus far are measured at the individual level. In addition, we include the $\log$ of city population as well as the share of foreigners at the city level as controls (these data are from Statistisches Bundesamt, 2012).

\section{Main Results}

In this section we explore the relationship between historical and present-day measures of anti-Semitism. We begin by showing that towns and cities with strong support for antiSemitic parties are still inhabited by individuals today who hold significantly stronger antiSemitic attitudes. Next, we analyze where this persistence comes from. Individuals who report more agreement in the family and among friends are also showing greater persistence of past attitudes in the same location. In addition, places that assimilate migrants to a greater extent also have higher levels of long-term transmission of anti-Semitic views.

\footnotetext{
${ }^{19}$ Because not all these variables are measured at a 1-7 scale, we prefer the principal component over the average.
} 


\section{IV.A. Baseline Findings}

Our main results are derived from a simple regression for individual $i$ living in city $c$, using different indicators for anti-Semitic sentiment $\left(A S_{i c}\right)$ :

$$
A S_{i c}=\alpha+\beta \text { Hist }_{c}+\gamma X_{i c}+\varepsilon_{\text {ic }}
$$

where $\mathrm{Hist}_{c}$ represents our three historical measures of anti-Semitic attitudes at the city level, $A_{S V O T E}{ }^{19 C}, N_{S V O T E}^{20 s}$, and NSVOTE ${ }^{30 s} . X_{i c}$ is a set of control variables, including age, educational attainment, and political orientation at the individual level, as well as population and the share of foreigners at the city level. We cluster all standard errors at the city level. Whenever we use the binary $A S^{\text {comm }}$ as dependent variable, we run Probit regressions; for $A S^{\text {broad }}$ (which varies continuously between 1 and 7) we use OLS.

Table 4 reports our baseline results for the two dependent variables $A S^{\text {broad }}$ and $A S^{\text {comm }}$. The table is organized by three subsamples: Panel A reports results for the full sample of individuals from the ALLBUS survey, including immigrants and Germans whose immediate ancestors came from abroad. Panel B includes only individuals with at least 2 generations of German ancestors. As one would expect, the coefficient indicating persistent anti-Semitism increases; the level of statistical significance is very similar to Panel A.

\section{[insert Table 4 here]}

As columns 1 and 4 show, both $A S^{\text {broad }}$ and $A S^{\text {comm }}$ are strongly correlated with anti-Semitic votes in Germany between 1890 and 1912, ASVOTE ${ }^{19 C}$. An eight-percentage point increase in the vote for anti-Semitic parties in Imperial Germany (which corresponds to one standard deviation) is associated with a rise in today's broad anti-Semitism by about 0.1 (which corresponds to .09 standard deviations of $A S^{\text {broad }}$ ). The Probit coefficients in column 4 imply that an eight-percentage point rise in $A S V O T E^{19 C}$ is associated with an increase in the fraction of strongly anti-Semitic individuals by approximately one percentage point. ${ }^{20}$ This is large, given that the sample mean for committed anti-Semites is 4.7 percent.

$N_{S V O T E}{ }^{20 C}$ is not significantly correlated with $A S^{\text {broad }}$, but it is strongly correlated with

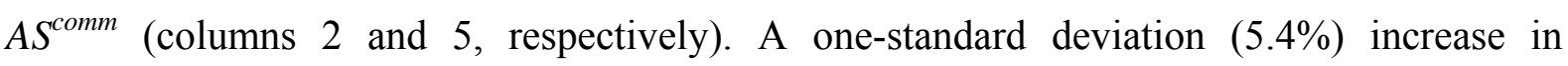
NSVOTE ${ }^{20 C}$ is associated with a $0.8-1.1$ percentage point rise in the proportion of committed anti-Semites today. Columns 3 and 6 in Table 4 show that Nazi votes in the 1930s $\left(N S V O T E^{30 C}\right)$ are weakly correlated with $A S^{\text {broad }}$ but strongly correlated with $A S^{\text {comm }}$. A onestandard deviation $(10.2 \%)$ increase in the 1930 s NSDAP vote translates into a rise in $A S^{\text {broad }}$

\footnotetext{
${ }^{20}$ The latter is obtained by using the Probit coefficients to (i) calculate the predicted probability of $A S^{\text {comm }}=1$ for the mean individual in the mean city, and (ii) repeat this exercise for the mean individual in a (hypothetical) city with ASVOTE $^{19 C} 1 \%$ above the mean.
} 
by about $0.5-0.7$ standard deviations, and into an increase in $A S^{\text {comm }}$ by $0.8-1.3$ percentage points.

Results are very similar across the three different subsamples, as shown in Panels A-C. In the following we restrict attention to individuals with German nationality and two generations of German ancestors, i.e., to the subsample used in Panel C.

Next, we include a set of control variables in our regressions and show that our results are robust (Table 5). Coefficients are similar in size and significance to those reported in Table 4. Education (in particular, college and beyond) is associated with significantly lower antiSemitism. The relationship between age and anti-Semitic attitudes is increasing and concave. In addition to these individual controls, we also include city characteristics. Individuals in larger cities are on average less anti-Semitic. Finally, a larger share of foreigners is associated with higher anti-Semitism.

\section{[insert Table 5 here]}

To check whether our results may be driven by city characteristics that did not change over time, we include a number of control variables from the 1925 German census in Table 6 . The historical percentage of protestants is (weakly) negatively associated with anti-Semitism today, while the percentage of Jews is (weakly) positive - in cities that had a larger share of Jewish population in 1925, committed anti-Semitism is somewhat higher today. The historical employment share in industry is positively associated with anti-Semitism today; the same is true for agriculture, albeit less significantly so. ${ }^{21}$ Finally, neither the percentage of self-employed in retail and trade (a prominent profession among Jews) nor the share of bluecollar workers are significantly associated with our measures of today's anti-Semitism. Most importantly, our main results do not change when including city-level characteristics from $1925 .^{22}$

\section{[insert Table 6 here]}

\section{IV.B. The Role of Consensus}

Our main results show that towns and cities in Germany that supported anti-Semitic parties between 1890 and 1933 still exhibit significantly higher levels of anti-Semitism today. This

\footnotetext{
${ }^{21}$ The excluded employment group is services, which is consequently negatively correlated with modern-day anti-Semitic sentiments.

${ }^{22}$ Note that in contrast to $N S V O T E^{20 C}, N_{S V O T E}{ }^{30 C}$ is now significantly correlated with $A S^{\text {broad }}$. This can be explained by the fact that $N_{S V O T E}{ }^{20 C}$ reflects extreme anti-Semitic attitudes in the 1920 s, when the Nazi party had a strong anti-Semitic focus and received relatively few votes (about $6.5 \%$ in 1924, and $2.6 \%$ in 1928). In contrast, votes for the Nazi party in the 1930s, and for anti-Semitic parties in the late Empire is a less radical and more mainstream form of partisan voting. Our results suggest that attitudes persisted at the local level depending on the level of historical radicalization: Extreme voting in the 1920s predicts extreme attitudes today; more broad-based anti-Semitism in the past is associated with generally higher levels of disliking Jews and antiJewish views.
} 
holds despite radical social, political, cultural, and economic changes in the interim, and despite the fact that almost no Jews continue to dwell in Germany. In this section, we analyze a number of channels that contribute or undermine the transmission of cultural attitudes. We differentiate between vertical transmission from parents to children and horizontal transmission between peers (but not family members) living in the same locality at the same time.

The importance of horizontal and vertical transmission is also highlighted by the role of consensus. The 1996 ALLBUS questionnaire asks asked respondents whether there was a general agreement regarding foreigners (a) within their family and (b) among their friends. On average, about $75 \%$ of individuals reported consensus within the family, and $69 \%$ among friends. We find that individuals who live in environments with high levels of agreements are also much more likely to show persistence of historical attitudes towards Jews; in contrast, transmission is weak or zero where friends and family do not agree with regard to foreigners.

In Panel A of Table 7, we run our baseline regressions with controls for the subset of respondents who report consensus about foreigners within their family. Despite the lower sample size, our results show significant persistence of anti-Semitism for most indicators and outcome variables. ${ }^{23}$ Most coefficients are substantially larger than those in Table 5 (which includes the same controls). This suggests that transmission of anti-Semitism is strengthened by agreement within families. Panel B provides further evidence that the converse is true, too. For respondents from families with no consensus about foreigners there is little persistence. In fact, the coefficients for most measures of historical anti-Semitism are negative; one is significant and negative, and one is positive and significant. While the mere insignificance of coefficients could be due to the substantially smaller sample size in Panel B, the fact that most coefficients are negative supports the interpretation that persistence is indeed much weaker.

\section{[insert Table 7 here]}

Panels $\mathrm{C}$ and $\mathrm{D}$ repeat the exercise for consensus among friends. We find a similar pattern as for families. In Panel C - where respondents report agreement - coefficients are substantially larger than in our baseline specification in Table 5. In the absence of agreement, persistence weakens (Panel D). In combination, the results in Table 7 suggest that both family influence as well as peer effects are important drivers of the persistence of cultural traits such as anti-

\footnotetext{
${ }^{23}$ The sample size is reduced throughout this analysis because the consensus variables are only available for one of the two years in which questions were also asked about the attitude towards Jews.
} 
Semitism. What it does not tell us is if areas with consensus breeds persistence, or if persistence causes consensus. $^{24}$

\section{IV.C. Peer Effects}

To take this analysis further, we examine attitudes adopted by immigrants from their German neighbors. We focus on xenophobia - a trait that immigrants should a-priori be unlikely to adopt. The left panel in Figure 3 plots our measure of xenophobia for immigrants against that for Germans living in the same town. First generation immigrants have attitudes towards foreigners that are essentially uncorrelated with those of Germans living in the same location. However, the same is not true of second-generation immigrants. These converge to the views of Germans in the same city, even on an unlikely issue such as disliking foreigners. This suggests that (i) first-generation immigrants do not systematically choose or avoid more xenophobic towns in Germany; (ii) descendents of immigrants that grow up in Germany adapt to local levels of xenophobia; (iii) the transmission likely occurs because of interactions between second-generation immigrants and local Germans (e.g., in school).

\section{[insert Figure 3 here]}

To test the link econometrically, we use the following specification:

$$
X_{\text {ENOIM }} \text { ic }=\alpha+\beta X \text { ENOG }_{c}+\gamma X_{i c}+\varepsilon_{i c},
$$

where $X E N O I M_{i c}$ is our principal component measure for xenophobia (calculated for first and second generation immigrants) at the individual level, and $X E N O G_{C}$ - is the average of the same measure for the local German population at the city level. As before, we cluster standard errors at the level of the city or town. $X_{i c}$ are the same controls as the ones used above. Table 8 shows that there is no significant association between the two measures for the 323 first-generation immigrants in our sample (column 1). ${ }^{25}$ The same is true for the subsamples of younger and older first-generation immigrants (columns 2 and 3). However, there is a strong correlation between xenophobia among local Germans and secondgeneration immigrants (columns 4-6), and the coefficient is increasing in age, i.e., in the time that second-generation immigrants have been exposed to local German culture.

\section{[insert Table 8 here]}

Next, we examine the horizontal transmission of anti-Semitic attitudes. We split our sample into two - one half where the assimilation of immigrants $\left(2^{\text {nd }}\right.$ generation) in terms of xenophobic attitudes is above the median, and the other half where it is below. We then test if

\footnotetext{
${ }^{24}$ Our results are not about city-level differences in consensus overall. Instead, for those individual respondents that report consensus, the anti-Semitic past of a given city matters relatively more.

${ }^{25}$ Positive coefficients suggest that there is some degree of assortative matching between migrants and their place of residence.
} 
those cities where cultural cohesion and the pressure for conformity is higher - where second-generation immigrants become as xenophobic as the locals - also show more longrange transmission of anti-Semitism. Table 9 demonstrates that this indeed is the case. We find positive interaction effects in all regressions (Panel A); implied coefficients are higher for the high assimilation group in all cases (Panel B). In particular, the pattern of persistence is strong for more extreme forms of anti-Semitism in those areas where locals "co-opt" migrants' children into thinking along the same lines as themselves.

[insert Table 9 here]

\section{Policy and the Malleability of Beliefs}

How malleable are beliefs? How much can deliberate policy intervention shape and change them? In this section, we look at two sources of variation - the differential effect of Nazi indoctrination, which varied by birth cohort, and differences in Allied occupation policies after 1945 .

\section{V.A. Learning to Hate}

We analyze if growing up under Nazi rule had a lasting effect on attitudes later in life. Our approach is similar to Malmendier and Nagel (2011), who use cohort-specific shocks in the past as a source of identifying variation for present-day behavior. We find that anti-Semitic attitudes are particularly pronounced for ALLBUS respondents who grew up under the Nazi regime. This cannot be explained by a simple age effect. We also show that those born in a social environment that was sceptical about Nazi ideology were much less affected by indoctrination than those from areas with a more compatible world view.

The left panel of Figure 4 shows broad anti-Semitism for birth cohorts between 1910 and $1980 .^{26}$ There is a clear downward trend in broad anti-Semitism - people born later in the last century are less anti-Semitic. The trend is statistically highly significant, as indicated by the tight $95 \%$ confidence intervals. Xenophobia similarly depends on age; the downward trend is even stronger.

\section{[insert Figure 4 here]}

This looks strikingly different for committed anti-Semites (right panel of Figure 4). Among the birth cohorts of the decades 1920,30 , and 40 , about $7 \%$ of respondents show committed

\footnotetext{
${ }^{26}$ Each birth cohort decade represents the 10 years around the respective value - for example, the 1930 cohort includes all individuals born between 1925 and 1934.
} 
anti-Semitic attitudes - almost double the percentage after $1950 .{ }^{27}$ The 1930 birth cohort has the highest share of committed anti-Semites. At the end of WWII, these individuals were between 11 and 21 years old; the youngest among them had been affected by the Nazi regime throughout their entire childhood, and the oldest, from age 9 onwards.

Finally, we repeat the analysis for residuals from a regression of $A S^{\text {broad }}$ on XENO and Rightwing. ${ }^{28}$ This approach filters out those components from broad anti-Semitism that are also correlated with xenophobia and right-wing political attitudes. Thus, the residual reflects a specific anti-Semitic view. The triangles in the right panel of Figure 4 show the averages of the residual by birth cohort, together with the $95 \%$ confidence interval. The trend is remarkably similar to the one for $A S^{\text {comm }}$.

Next, we show regression results for three birth cohorts: individuals born before 1920, those born between 1920-39, and those born between 1940-59. The 1920-39 cohort spent all or part of their childhood and early adulthood under Nazi reign. Table 10 shows that individuals in this cohort also have the most pronounced anti-Semitic attitudes. According to our Probit estimates in columns 4-6, they are more than twice as likely to be committed anti-Semites than individuals in the control group (born after 1959). Together, the results in Figure 4 and Table 10 suggest that Nazi indoctrination - in school, through propaganda, and in youth organizations - successfully instilled strongly anti-Semitic attitudes in the cohorts that grew up in 1933-45, and that these attitudes are still visible today.

\section{[insert Table 10 here]}

By including our three election-based measures for historical anti-Semitism, Table 10 also shows that our main results are not affected when including cohort dummies. In addition, Panel B shows that persistence is not solely driven by individuals born in 1920-39. When excluding this cohort from our main regressions, the results are almost unchanged.

Did the Nazi regime successfully instil anti-Semitic sentiments in all social and political classes, or were some particularly receptive or resistant? In the following we show that cities dominated by left and center-left parties in the 1920s were significantly less receptive to adapting anti-Semitic attitudes. The opposite is true for cities with high vote shares for rightwing and center-right parties. We define the variable CenLeft20s as the average vote share of the Communist Party (KPD) and the center-left Social Democratic Party (SPD) in the 1924 and 1928 elections. CenLeft30s is the average for the same parties in the 1930 and 1933

\footnotetext{
${ }^{27}$ These decades comprise people born between 1915 and 1944. Those born in 1915 lived under Nazi reign from their $18^{\text {th }}$ birthday (in 1933) onward, which includes the "impressionable years" between 18 and 25 (Krosnick and Alwin 1989). Individuals in the 1940 cohort were exposed to between 1 and 10 years to Nazi reign. While a direct impact of Nazi indoctrination is unlikely for the youngest, their parents spent much of their youth and early adulthood under Nazi rule.

${ }^{28}$ The coefficients are $.528(.018)$ and .253 (.046) for XENO and Rightwing, respectively (with standard errors in parentheses).
} 
elections. Finally, CenRight20s is the average vote share of the right-wing German National People's Party (DNVP), the center-right German People's Party (DVP), and the Centre Party (Zentrum) in the 1924 and 1928 elections. $^{29}$

Table 11 includes these variables in our main regression setup, as well as their interaction with a dummy for the 1920-39 birth cohort, $I^{1920-39}$. The interaction term is negative and significant for both CenLeft20s and CenLeft30s. This suggests that in cities with a larger proportion of left voters, the Nazi party was less successful at instilling anti-Semitic preferences. Both CenLeft20s and CenLeft30s have a mean of .17 and a maximum size of approximately .35. Given the interaction coefficients of roughly -1.3 from Columns 1 and 2 , this implies that in cities with the largest vote shares for left parties, the 1920-39 birth cohort does not show significantly higher levels of broad anti-Semitic attitudes today (0.57$1.3 \times 0.35=0.115)$. The same is true for committed anti-Semitism in columns 4 and 5 .

\section{[insert Table 11 here]}

In columns 3 and 6 we show that in cities with higher shares of center and right voters, antiSemitic attitudes are significantly stronger for the 1920-39 birth cohort. ${ }^{30}$ This suggests that the Nazis were particularly successful at instilling anti-Semitism in cities that already had a larger share of the population on the right of the political spectrum. The interaction results are in line with our earlier findings that the attitudes of friends are important for the transmission of anti-Semitism from the 1890 to the present. The results here suggest that the same is true for instilling anti-Semitic sentiments in the local population: the formation of cultural or political preferences is particularly effective where the local beliefs are already homogenous and broadly compatible with the new ideology.

\section{V.B. "Denazification"}

Did denazification policies of the Allies lower the local level of anti-Semitic sentiment? To answer this question, we exploit the fact that denazification policies and measures varied substantially between the different zones of occupation. As described in Section II.D, the Soviet zone witnessed rigorous prosecution and conviction of Nazi officials, but mitigated for those who signed up to the new regime. In contrast, in the American zone, attempts to prosecute former Nazi officials and party members were highly ambitious and comprehensive, but results were disappointing; the process fed German resentment due to a perceived lack of unfairness. In contrast, the British occupation forces were more pragmatic in their approach, focusing on high-ranking officials.

\footnotetext{
${ }^{29}$ To avoid that CenRight20s captures early sympathy with the Nazi Party program, we do not include Nazi Party votes in this variable.

${ }^{30}$ Results are very similar for when using center and right-wing votes from the 1930s instead. However, these are dominated by the NSDAP's electoral success - which we already analyzed.
} 
Before we begin our analysis, we examine historical voting patterns. ${ }^{31}$ Figure 5 shows the standardized voting results (ALLVOTE). Overall, the distribution of vote shares for antiSemitic parties and for the Nazi party are relatively similar across the different regions. There are relatively more locations with extreme behavior in the American and British zone than in the Soviet one. Our joint measure ALLVOTE is about 0.1 standard deviations lower in cities that later belonged to the British sector. This is driven by anti-Semitic votes in Imperial Germany and by votes for the Nazi party in the 1920s. Votes for the Nazi party in the 1930s are very similar across the three occupation zones. In sum, there are pre-WWII differences in anti-Semitic votes.

\section{[insert Figure 5 here]}

In Figure 6, we plot distributions of our measure of broad anti-Semitism, by zone of occupation. The American zone has the highest levels today; the British has the lowest, and the Soviet zone falls half-way between the two. Is this a reflection of zone policy differences, or does it reflect pre-established racial hatred? We regress today's level of broad antiSemitism on historical vote shares (ALLVOTE), and calculate the residuals. These now reflect any existing differences in historical anti-Semitism. Figure A.2 in the appendix plots the distributions, which are almost identical with the original ones. ${ }^{32}$

\section{[insert Figure 6 here]}

Next, we analyze the question of differential perpetuation of anti-Semitism using regression analysis. Panel A in Table 12 shows that today's level of anti-Semitic sentiment is substantially lower in what used to be the British and Soviet occupation zones, relative to the American zone (the omitted dummy variable in the regression). Respondents in the French occupation zone is not significantly different from the American zone. This is true for both broad and for committed anti-Semitism. We also control for the level of historical racial hatred by including the three vote-based measures of earlier attitudes. The results are nearly identical. Even after controlling for the relationship between past and present levels of Jewhatred overall, we find that the Soviet and British zones have markedly lower anti-Semitism.

\section{[insert Table 12 here]}

These results suggest a stronger modification of historical anti-Semitic beliefs in some zones of occupation than in others. We interpret this as follows: Both the British and Soviet pursued denazification by prosecuting high-ranking Nazi officials early on. Lower-ranking party members were less affected. This produced "buy-in" from the local population, allowed

\footnotetext{
${ }^{31}$ There are few cities in our sample from the French zone.

${ }^{32}$ If we conduct our exploratory data analysis using our measure of committed anti-Semites, we obtain very similar results (uncorrected: American zone $-6.7 \%$; British $-3.9 \%$; Soviet $-3.0 \%$; French $-7.6 \%$; residual after correcting for ALLVOTE: American - 1.9\%; British - -0.6\%; Soviet - -1.7\%; French - 2.9\%).
} 
ordinary Germans to distance themselves from central tenets of Nazi ideology, and convinced them that anti-Semitism was wrong. This is also in line with Acemoglu and Jackson (2011), who emphasize the importance of removing prominent individuals in generating cultural change. Of course, Soviet policies were different in a number of dimensions; the existence of the GDR for 40 years makes it harder to identify the effect of occupation itself. For the Western zones, however, such a comparison is easier since policies after 1949 were broadly similar - here, the only "treatment" difference was the denazification policy of the occupiers.

Next, we use geographical proximity to identify similar towns in different occupation zones, and focus on the contrast between the British and American zones of occupation (Table 13). We analyze a sample of locations within $100 \mathrm{~km}$ of the border between the US and British sector. ${ }^{33}$ As before, the results indicate that the area of British occupation is less anti-Semitic today.

\section{[insert Table 13 here]}

\section{Robustness and Interpretation}

In this section, we analyze the robustness of our findings, and examine some of them in finer detail. We investigate if the use of alternative estimators or different treatment of the data suggests alternative conclusions. In addition, we demonstrate that our main results do not only hold for average vote shares across several elections, but also for individual ones. Modern-day anti-Semitism is closely related to a broader pattern of right-wing sentiment or xenophobia, but it is not fully explained by it - past attitudes matter over and above the close link between xenophobia and anti-Semitism in general. Finally, we test if migration after 1945 and bomb destruction influence our results.

\section{VI.A. Anti-Semitism, Xenophobia and General Right-wing Attitudes}

Do our results reflect the persistence of a broader cultural trait - a general dislike to foreigners, or a more right-wing world view, of which anti-Semitism is merely one element? In the following, we show that this is not the case. Our results capture specific anti-Semitic sentiment. We use our measure of xenophobic attitudes at the individual level, XENO, as well as a measure of right-wing political orientation (Rightwing). Both variables are strongly correlated with today's anti-Semitic attitudes: the correlation between XENO and $A S^{\text {broad }}$ and $A S^{\text {comm }}$ is .51 and .17 , respectively. Nonetheless, we show in Table 14 that historical anti-

\footnotetext{
${ }^{33}$ We restrict attention to these two sectors - excluding the Soviet zone - because they had the same federal institutions, and are thus more readily comparable along other dimensions.
} 
Semitism at the city level is correlated with present-day anti-Jewish attitudes even after controlling for individual xenophobia and right-wing political views.

\section{[insert Table 14 here]}

We use the coefficients in column 1 to illustrate the magnitudes involved: Xenophobia has is a strong predictor of anti-Semitism at the individual level. ${ }^{34} \mathrm{~A}$ one-standard deviation increase in XENO raises the probability of showing committed anti-Semitism by 4 percentage points (compared to a baseline of 2.6\%), according to our Probit estimation results in columns 4-6. Subjects that position themselves on the extreme right of the political scale also show higher $A S^{\text {broad }}$ and are up to 1.5 percentage points more likely to be committed antiSemites, as by our measure $A S^{\text {comm }}$ (columns 4-6). A comparison with Table 5 shows that the coefficients of the historical voting results are not consistently smaller even after controlling for xenophobia and right-wing worldview. The results in Table 14 suggest that the pattern of persistence at the city level identifies specifically anti-Semitic attitudes, while there is also an additional association at the individual level that is not surprising - more xenophobic respondents are also more anti-Semitic.

\section{VI.B. Individual Election Results}

In this section, we show that results hold for individual elections in the $19^{\text {th }}$ and early $20^{\text {th }}$ century, and not only for the summary measures used so far. We begin by using vote shares of anti-Semitic parties for each of the six election years between 1890 and 1912. Panel A of Table 15 shows that there is a strong and positive association between anti-Semitic votes and broad anti-Semitic sentiment today - across all individual elections. The coefficients also have the same order of magnitude as those reported for the average (ASVOTE ${ }^{19 C}$ ) above. The same is true for the link with strong anti-Semitism (Panel B).

\section{[insert Table 15 here]}

Table 16 uses individual results for Nazi elections over the period $1924-33 .{ }^{35}$ We find that committed anti-Semitism today is strongly and significantly associated with voting in individual elections (Panel B); for broad anti-Jewish attitudes, there is a positive association that fails to reach conventional significance levels (Panel A). This suggests that the often erratic year-to-year swings of electoral success are less helpful in identifying long-run persistence of broad but less extreme Jew-hatred than average voting results (Table 6); averages give less weight to passing ups and downs, and hence contain less noise. For committed anti-Semitism, the explanatory power of NS electoral success declines: The coefficient for the Nazi party vote share is smaller by $30 \%$ in 1930 than in 1928, and declines

\footnotetext{
${ }^{34}$ Note that $X E N O$ is a standardized measure, while all vote shares are between 0 and 1.

${ }^{35}$ We use the four elections for which data are available at the municipality level.
} 
by another $40 \%$ for the 1933 election. This suggests that those places that fell for the Nazi party's appeal early are particularly imbued with committed anti-Jewish sentiment today.

[insert Table 16 here]

\section{VI.C. Bomb Destruction and Mass Population Movements}

The Second World War was followed by large-scale population movements. More than 10 million Germans fled from the Eastern territories. The German Association of Cities provides information on the inflow of expellees into cities. The share of expellees in the recipient cities' population in 1956 ranges from $5 \%$ to $35 \%$ in our sample, with a median of $17 \%$. In Table 17 we use this information to test whether mass population inflow weakened the transmission of anti-Semitism at the local level. Panel A shows that the difference in persistence across the two subsamples is statistically significant for most specifications. This is captured by the negative (and mostly significant) interaction terms between a dummy for above-median expellee share and our three historical measures for anti-Semitism. Panel B reports the implied total coefficients for the above- and below-median subsamples. We find that most previous results hold for the subset of cities with below-median share of expellees. However, in cities with above-median inflow of expellees, persistence is weakened - the implied total coefficients are lower, and one is negative and insignificant. These results suggest that large-scale inflows of population from distant locations undermine the persistence of local cultural traits. The result also suggests that horizontal transmission of attitudes from locals does not fully compensate the attenuating effect of massive inflows of outsiders.

\section{[insert Table 17 here]}

The Second World War also caused substantial destruction across German cities. About 40\% of the housing stock was destroyed. There were 13 cubic meters of rubble for every city dweller. The Nazi propaganda tried to blame the war in general (and the "terror bombing" in particular) on an international Jewish conspiracy led by Britain and America. Was this propaganda successful? We use city-level data on rubble and destruction of flats from the German Association of Cities (Deutscher Städtetag, 1949). Table 18 suggests that it was not. Neither the amount of rubble (Panel A) nor the percentage of destroyed flats (Panel B) is statistically significantly associated with today's anti-Semitism. ${ }^{36}$

\section{[insert Table 18 here]}

Several reasons can be cited for this non-finding. Inhabitants of bombed cities experienced the consequences of Nazi aggression first-hand in a way that citizens elsewhere did not. This

\footnotetext{
${ }^{36}$ The same is true when restricting attention to the 1920-39 birth cohort which was particularly strongly affected by bomb destruction and Nazi propaganda.
} 
may have undermined their susceptibility to Nazi doctrines. In addition, the bombing caused wide-scale displacement of population.

\section{VI.D. City-Level Regressions and Matching Estimation}

In Table 19 we show that our results also hold at the more aggregate level. Panel A repeats our baseline analysis from Table 5 at the city level; it confirms our previous results. ${ }^{37}$ The same is true for Panel B, where we use Poisson Maximum Likelihood estimation instead of OLS. This addresses the fact that $A S^{\text {comm }}$ is highly right-skewed. Next, we present propensity score matching results in Panels $\mathrm{C}$ and $\mathrm{D}$. The treatment variable is whether the vote shares from our three historical measures (ASVOTE ${ }^{19 C}, N_{S V O T E}{ }^{20 s}$, and $N S V O T E^{30 s}$ ) is above the median. In Panel C, our standard set of controls (see Table 5) serve as matching variables. In Panel D, we also match by geographic longitude and latitude, so that we compare nearby cities. The matching estimation delivers weaker results for broad anti-Semitism (Columns 13 ), but confirms our results for committed anti-Semitism (Columns 4-6).

[insert Table 19 here]

\section{Conclusion}

Our study demonstrates the persistence of racial prejudices at the local level over more than a century - and across one of the greatest discontinuities in recorded history. Today, there are still many more individuals with anti-Jewish beliefs in those towns and cities that voted for anti-Semitic parties during the period 1890-1912 or that supported the Nazi movement. We show that each of these historical variables correlates with attitudes today. They also correlate with xenophobia more generally, without distracting from the additional link with anti-Jewish beliefs.

We use the rich laboratory setting of Germany after 1945 to examine more closely why attitudes persisted in some locations, and among some groups, but not in all. Our study is - to our knowledge - one of the first that shows the importance of peer effects in the transmission of cultural norms. We show that areas that assimilate second-generation immigrants more also have higher persistence over the last century. In addition, where people agree with family and friends, they are more likely to transmit the same views on Jews across generations.

\footnotetext{
${ }^{37}$ Note that thus $A S^{\text {comm }}$ is the proportion of committed anti-Semites in each city. Since this is continuously distributed between 0 and 1, we now use OLS rather than Probit estimation when $A S^{\text {comm }}$ is the dependent variable. All control variables in Table 19 also reflect city-level averages.
} 
This study offers further evidence for the malleability of beliefs. Germans who grew up under the Nazi regime show more anti-Semitic tendencies in general than those born earlier or later; for committed anti-Semites with a consistent set of negative views about Jews, the effect is strong and significant. This suggests that Nazi indoctrination was highly effective in inculcating a "culture of hate." Interestingly, it only succeeded in areas with broadly conservative leanings in general, as proxied by the success of all right-of-center parties. In former strongholds of the social democrats and communists, there is no "Nazi youth effect."

Public policy in Germany towards Jews and racial hatred changed dramatically after 1945. Our finding of strong persistence at the local level - especially for those with extreme views - suggests that the massive program of denazification apparently did little to help the adoption of more enlightened attitudes. In the US and French zones of occupation, voting in the distant past - more than 3 generations ago - is still a good predictor of attitudes today. There is, however, one exception to this rule: the former British zone of occupation. There, past attitudes have no predictive powers for the present.

Differences in occupation policy help to explain lower persistence in the British sector. The US approach to denazification is widely considered as a failure (Herz 1948). It was overambitious, and inconsistency of implementation - especially the rapid and harsh punishment of low-level officials, while higher-ranking perpetrators escaped lightly - undermined the program's credibility and perceived fairness. In contrast, the British denazification was more pragmatic and limited in scope (Biddiscombe 2007). It focused on high-ranking officials involved in major crimes, and made removing them a priority. This policy enjoyed wider support among the public. The relative success of British denazification adds empirical support to recent models of social networks that underline the importance of influential 'prominent agents' in engendering cultural change (Acemoglu and Jackson 2011). 


\section{References}

Acemoglu, Daron, Hassan, Tarek A. and James A. Robinson. 2011. "Social Structure and Development: A Legacy of the Holocaust in Russia", Quarterly Journal of Economics 126(2): 895-946.

Acemoglu, Daron, and Matthew Jackson. 2011. "History, Expectations, and Leadership in the Evolution of Cooperation." Mimeo.

Akbulut-Yuksel, Mevlude, and Yuksel, Mutlu. 2011. "The Long-Term Direct and External Effects of Jewish Expulsions in Nazi Germany, " IZA Discussion Papers 5850.

Aghion, Philippe, Yann Algan, Pierre Cahuc, and Andrei Shleifer. 2010. "Regulation and Distrust." Quarterly Journal of Economics 125(3): 1015-49.

Alesina, Alberto, Paola Giuliano, and Nathan Nunn. 2011. "Fertility and the Plough." NBER Working Paper No. 16718.

Algan, Yann, and Pierre Cahuc. 2010. "Inherited Trust and Culture." American Economic Review 100(5): 2060-2092.

Bergmann, W., and R. Erb. 1997. Anti-Semitism in Germany: the post-Nazi epoch since 1945, trans. B. Cooper and A. Brown. London: Transaction Publishers.

Biddiscombe, Perry. 2007. The Denazification of Germany. Stroud: Tempus Publishing.

Bisin, Alberto, and Thierry Verdier, 2000. "'Beyond the Melting Pot': Cultural Transmission, Marriage, and the Evolution of Ethnic and Religious Traits." Quarterly Journal of Economics 115(3): 955-988.

Bisin, Alberto. 2001. "The Economics of Cultural Transmission and the Dynamics of Preferences." Journal of Economic Theory 97(2): 298-319.

Boyd, Rob and Peter J. Richerson.1985. Culture and the Evolutionary Process. Chicago: University of Chicago Press.

Boyd, Rob and Peter J. Richerson. 1995. "Why Does Culture Increase Human Adaptibility?" Ethology and Sociobiology 16: 125-143.

Brambor, Thomas, William R. Clark, and Matt Golder. 2006. "Understanding Interaction Models: Improving Empirical Analyses.” Political Analysis 14(1): 63-82.

Brennecke, Fritz. 1938. The Nazi Primer: Official Handbook for Schooling the Hitler Youth. New York: Harper \& Brothers.

Bromba, Michael and Wolfgang Edelstein. 2001. Das anti-demokratische und rechtsextreme Potenzial unter Jugendlichen und jungen Erwachsenen in Deutschland. Expertise für das Bundesministerium für Bildung und Forschung (BMBF). Bonn.

Burchardi, Konrad B., and Tarek Alexander Hassan. 2011. "The Economic Impact of Social Ties: Evidence from German Reunification," NBER Working Papers No. 17186.

Doepke, Matthias, and Fabrizio Zilibotti. 2008. "Occupational Choice and the Spirit of Capitalism," Quarterly Journal of Economics 123(2):747-793.

Emnid. 1989. Antisemitismus in Deutschland. Repräsentativumfrage. Bielefeld.

Fernández, Raquel, and Alessandra Fogli. 2009. "Culture: An Empirical Investigation of Beliefs, Work and Fertility.” American Economic Journal: Macroeconomics 1(1): 146-177.

Fernández-Villaverde, Jesús, Greenwood, Jeremy, and Nezih Guner. 2011. "From Shame to Game in One Hundred Years: The Rise in Premarital Sex and its Destigmitization," CEPR Discussion Papers No. 8667.

Frindte, W., Funke, F. and Jacob, S. 1999. "Gegenwärtige politische Orientierung und der Bezug zum Nationalsozialismus". In: W. Frindte (ed.), Fremde, Freunde, Feindlichkeiten. Sozialpsychologische Untersuchungen (S. 50-69). Opladen: Westdeutscher Verlag.

Goschler, Constantin. 1991. "The Attitude towards Jews in Bavaria after the Second World War." Leo Baeck Institute Yearbook 36 (1): 443-458. 
Grosfeld, Irena, Rodnyansky, Alexander and Ekaterina Zhuravskaya. 2011. "Persistent Antimarket Culture: A Legacy of the Pale of Settlement and of the Holocaust," CEFIR Working Papers No. w0145.

Guiso, Luigi, Paola Sapienza, and Luigi Zingales. 2008. “Long Term Persistence.” NBER Working Papers No. 14278.

Haverkamp, Alfred. 2002. Geschichte der Juden im Mittelalter von der Nordsee bis zu den Südalpen; Kommentiertes Kartenwerk. Hannover: Hahn.

Heck, Alfons. 1988. The Burden of Hitler's Legacy. Frederick, CO: Renaissance House.

Heilbronner, Oded. 2004. "German or Nazi Anti-Semitism?" In The Historiography of the Holocaust, edited by Dan Stone. New York: Palgrave Macmillan.

Herz, J. 1948. "The Fiasco of Denazification in Germany." Political Science Quarterly 63(4): 569-594.

Jha, Saumitra, 2008. "Trade, Institutions and Religious Tolerance: Evidence from India." Stanford University Research Paper No. 2004.

Judt, Tony. 2005. Postwar: a history of Europe. London: Pimlico.

Kaplan, Marion A (1999). Between Dignity and Despair: Jewish life in Nazi Germany. New York: Oxford University Press.

Katz, Jacob. 1980. From Prejudice to Destruction: Anti-Semitism, 1700-1933. Cambridge: Harvard University Press.

Katz, Jacob. 1994. Die Hep-Hep Verfolgungen des Jahres 1819. Berlin: Metropol-Verlag.

Kershaw, Ian. 1983. Popular Opinion and Political Dissent in the Third Reich. Bavaria, 1933-45. Oxford: Clarendon Press.

Krosnick, J. A., and D. F. Alwin. 1989. "Aging and Susceptibility to Attitude Change." Journal of Personality and Social Psychology 57: 416-425.

Longerich, Peter. 2010. Holocaust: The Nazi Persecution and Murder of the Jews. Oxford: University Press.

Malmendier, Ulrike, and Stefan Nagel. 2011. "Depression Babies: Do Macroeconomic Experiences Affect Risk-Taking?" Quarterly Journal of Economics, 126(1): 373-416.

Noelle-Neumann, Elisabeth and Ring, E. 1984. Das Extremismus-Potential unter jungen Leuten in der Bundesrepublik Deutschland. Allensbach: Institut fur Demoskopie.

Nolte, Ernst. 1987. Das Vergehen der Vergangenheit. Berlin: Ullstein.

Nunn, Nathan. 2008. "The Long-Term Effects of Africa's Slave Trades." Quarterly Journal of Economics, 123(1): 139-176.

Nunn, Nathan, and Leonard Wantchekon, 2011. "The Slave Trade and the Origins of Mistrust in Africa." American Economic Review 101(7): 3221-52.

Panahi, Badi. 1980. Vorurteile : Rassismus, Antisemitismus, Nationalismus in der Bundesrepublik heute. Frankfurt: Fischer.

Silbermann, Alphons. 1982. Sind wir Antisemiten? Ausmaß und Wirkung eines sozialen Vorurteils in der Bundesrepublik Deutschland; Köln.Spolaore, Enrico, and Romain Wacziarg, 2009. “The Diffusion of Development." Quarterly Journal of Economics 124(2): 469-529.

Stachura, Peter. 1978. "Der Kritische Wendepunkt? Die NSDAP und die Reichstagswahlen vom 20 Mai 1928." Vierteljahrshefte für Zeitgeschichte 26(1): 66-99.

Striesow, Jan. 1981. Die Deutschnationale Volkspartei und die Völkisch-Radikalen 19181922. 2 Bde. Frankfurt a. M.

Tabellini, Guido. 2008. "The Scope of Cooperation: Norms and Incentives.” Quarterly Journal of Economics 123(3): 905-950.

Tabellini, Guido. 2010. "Culture and Institutions: Economic Development in the Regions of Europe," Journal of the European Economic Association, 8(4): 677-716.

Teschke, J. 2001. Hitler's Legacy. New York: Peter Lang. 
Turner, I. 1989. "Denazification in the British Zone" in: Reconstruction in Post-War Germany, ed. I. Turner. Oxford: Berg Publishers, pp.239-68.

Toch, Michael. 2003. Die Juden im Mittelalterlichen Reich. München: Oldenbourg

Voigtländer, Nico and Hans-Joachim Voth. 2012. "Persecution Perpetuated: The Medieval Origins of Anti-Semitic Violence in Nazi Germany." Quarterly Journal of Economics 127(3), forthcoming.

Vogt, Timothy R. 2000, Denazification in Soviet-Occupied Germany: Brandenburg, 19451948, Cambridge and London: Harvard University Press.

Waldinger, Fabian. 2010. "Quality Matters: The Expulsion of Professors and the Consequences for PhD Students Outcomes in Nazi Germany", Journal of Political Economy, 118(4): 787-831.

Waldinger, Fabian 2012. "Peer effects in Science - Evidence from the Dismissal of Scientists in Nazi Germany", The Review of Economic Studies, forthcoming.

Welch, D. 1983. Nazi Propaganda: The Power and the Limitations. London: Croom Helm.

Walter, Dirk. 1999. Antisemitische Kriminalität und Gewalt. Bonn: Dietz.

Wawrzinek, Kurt. 1927. Die Entstehung der Deutschen Antisemitenparteien, 1873-1890. Berlin: Ebering.

Wehler, Hans-Ulrich. 1988. Entsorgung der deutschen Vergangenheit: Ein polemischer Essay zum Historikerstreit. Munich: C.H. Beck. 


\section{FIGURES}

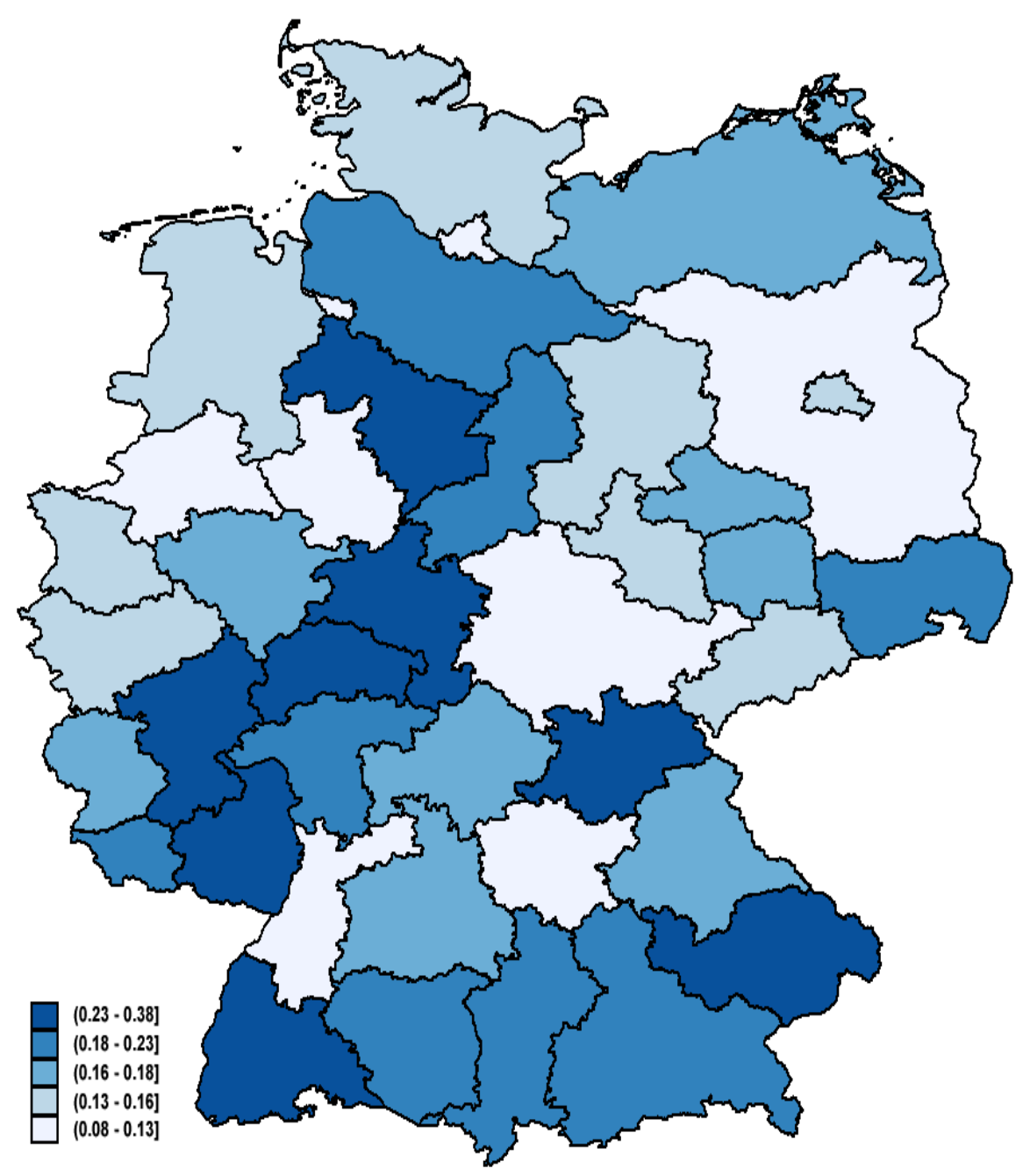

Figure 1: Distribution of Extreme Anti-Semitic Attitudes

Source: ALLBUS (1996, 2006). Percentage of the population that responds with answers 5 or higher to the question "Through their actions, Jews are partly responsible for their own persecution. Do you agree or disagree?" (Possible answers range from 1 to 7, with 1= "I do not agree at all" and 7="I agree entirely") 


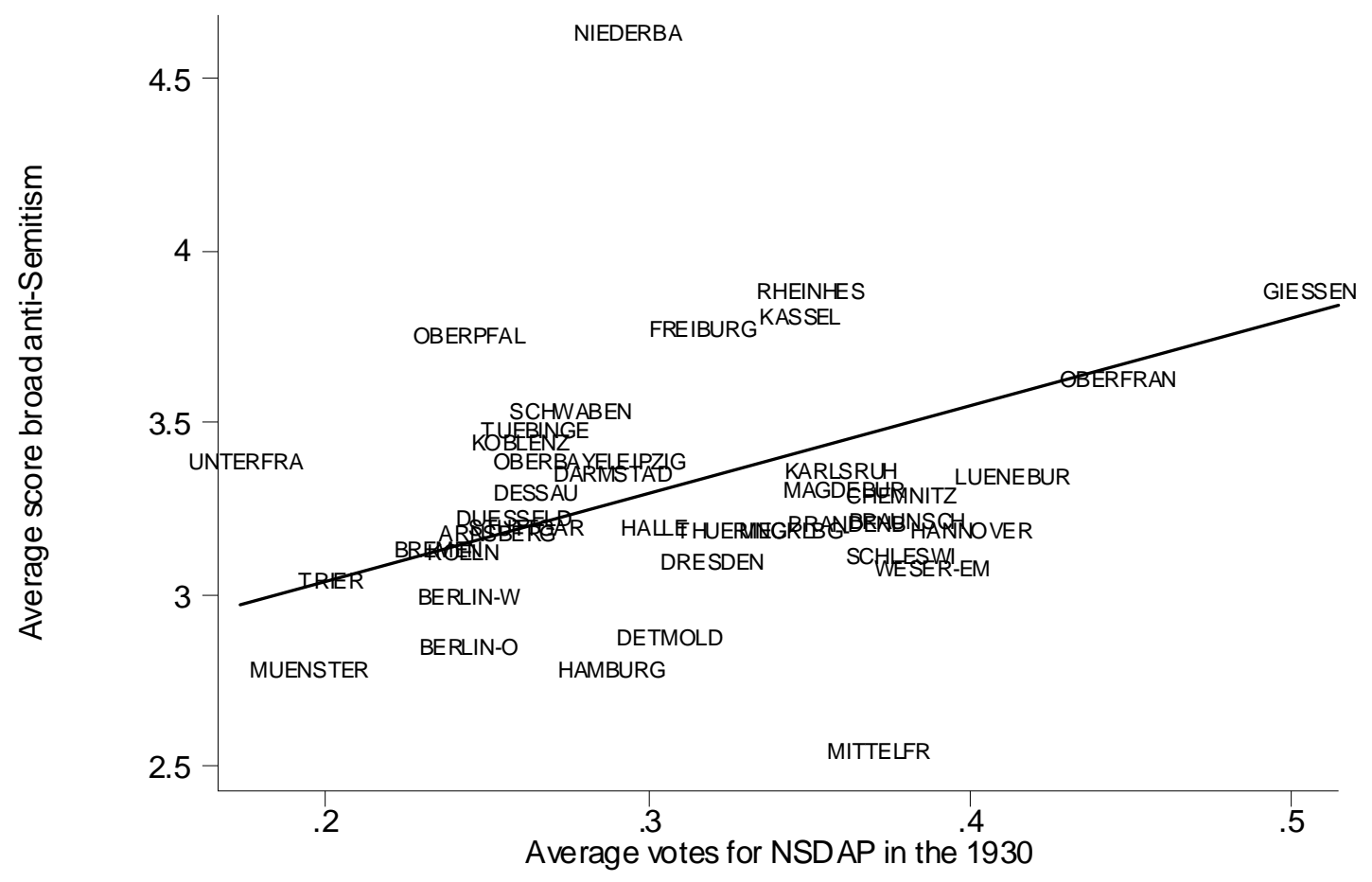

Figure 2: Broad Anti-Semitic Attitudes Today, by Nazi vote in the 1930s (aggregated at the level of prefecture)

Notes: Broad Anti-Semitism ( $A S^{\text {broad }}$ ) is the principal component of seven questions about attitudes towards Jews, taken from ALLBUS $(1996,2006)$. See Section III.A for details. 

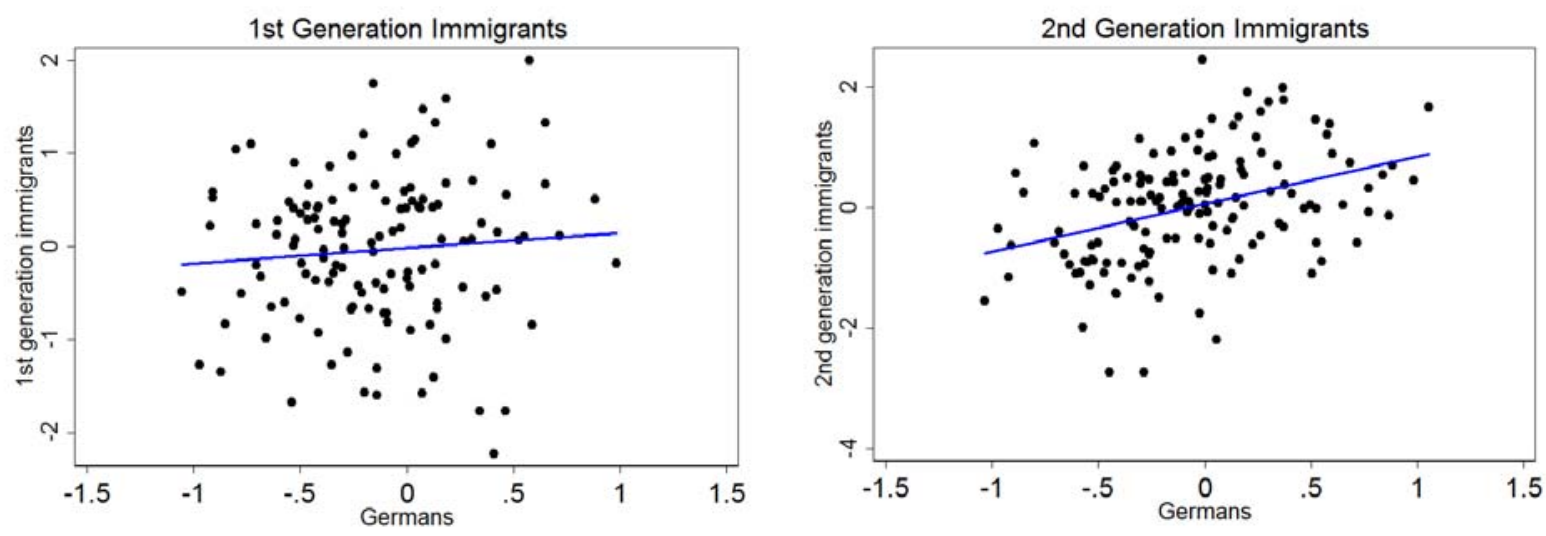

Figure 3: Xenophobia: First and second generation immigrants versus Germans

Source: ALLBUS (1996, 2006). Xenophobia measured as described in section III.A. "Germans" are individuals with German nationality, as well as both parents and all four grandparents from today's German territory. " 1 st $^{\text {st }}$ generation immigrants" are individuals without German nationality, and both parents were born outside of Germany (in its 1938 borders). "2 ${ }^{\text {nd }}$ generation immigrants" are individuals with German nationality, and both parents were born outside of Germany (in its 1938 borders). Note that WWII expellees from former German territories in the east are not included in any of the three categories. Regression lines: The line for $1^{\text {st }}$ generation immigrants has a slope of .16 (t-stat .91). The line for $2^{\text {nd }}$ generation immigrants has a slope of .75 (t-stat 5.26).
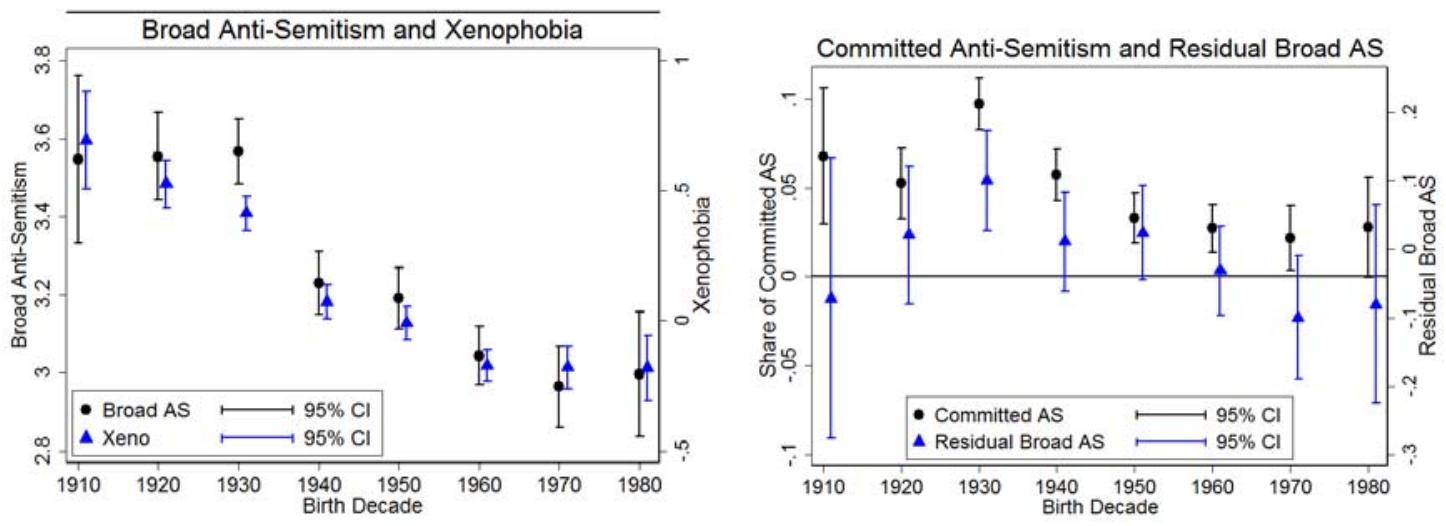

Figure 4: Anti-Semitism and Xenophobia by Birth Cohort

Source: ALLBUS data. See section V.C for details. 


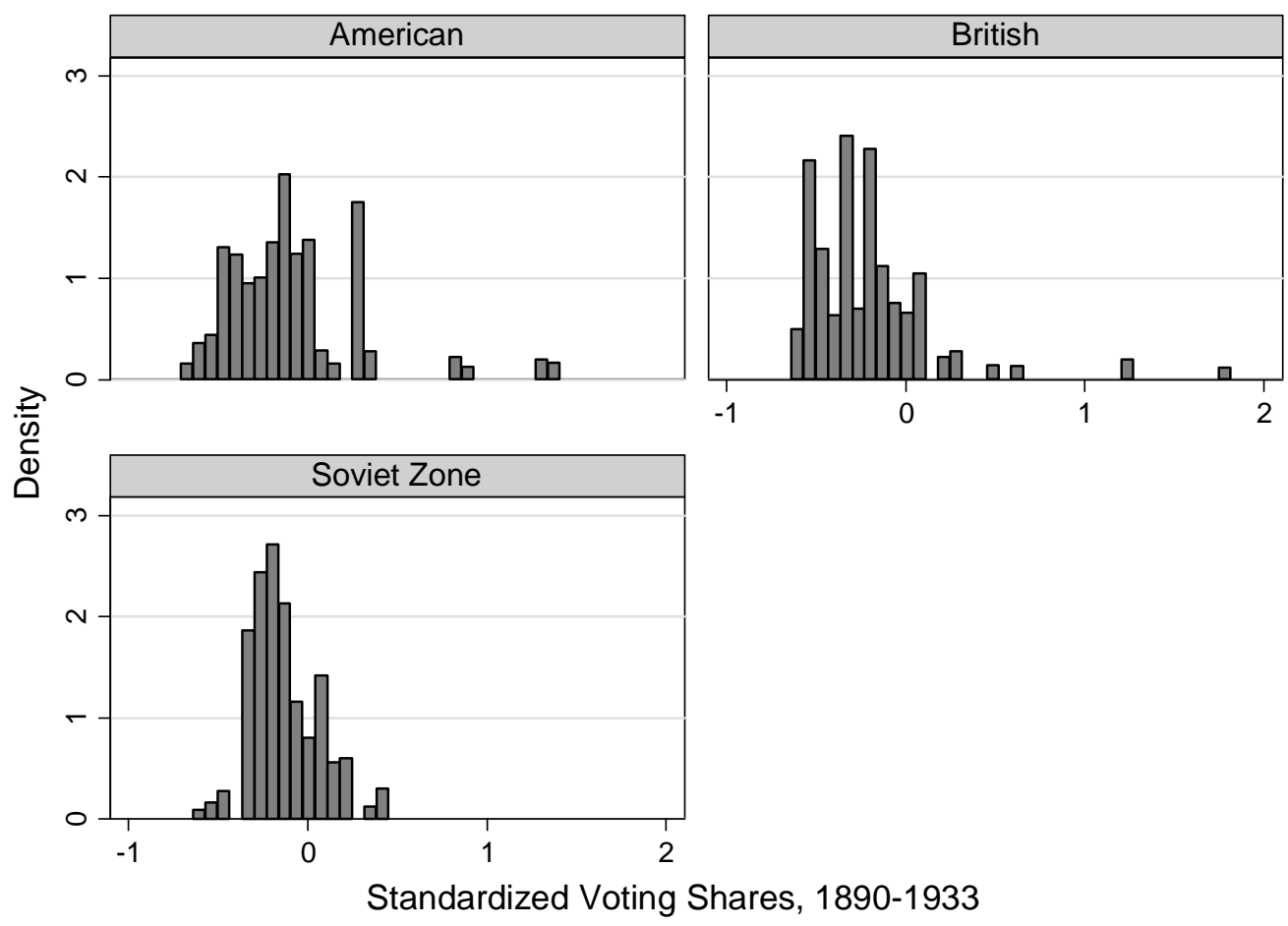

Figure 5: Distribution of Standardized Voting Results, by Occupation Zone Source: ALLBUS data (see Section III.A for details). 


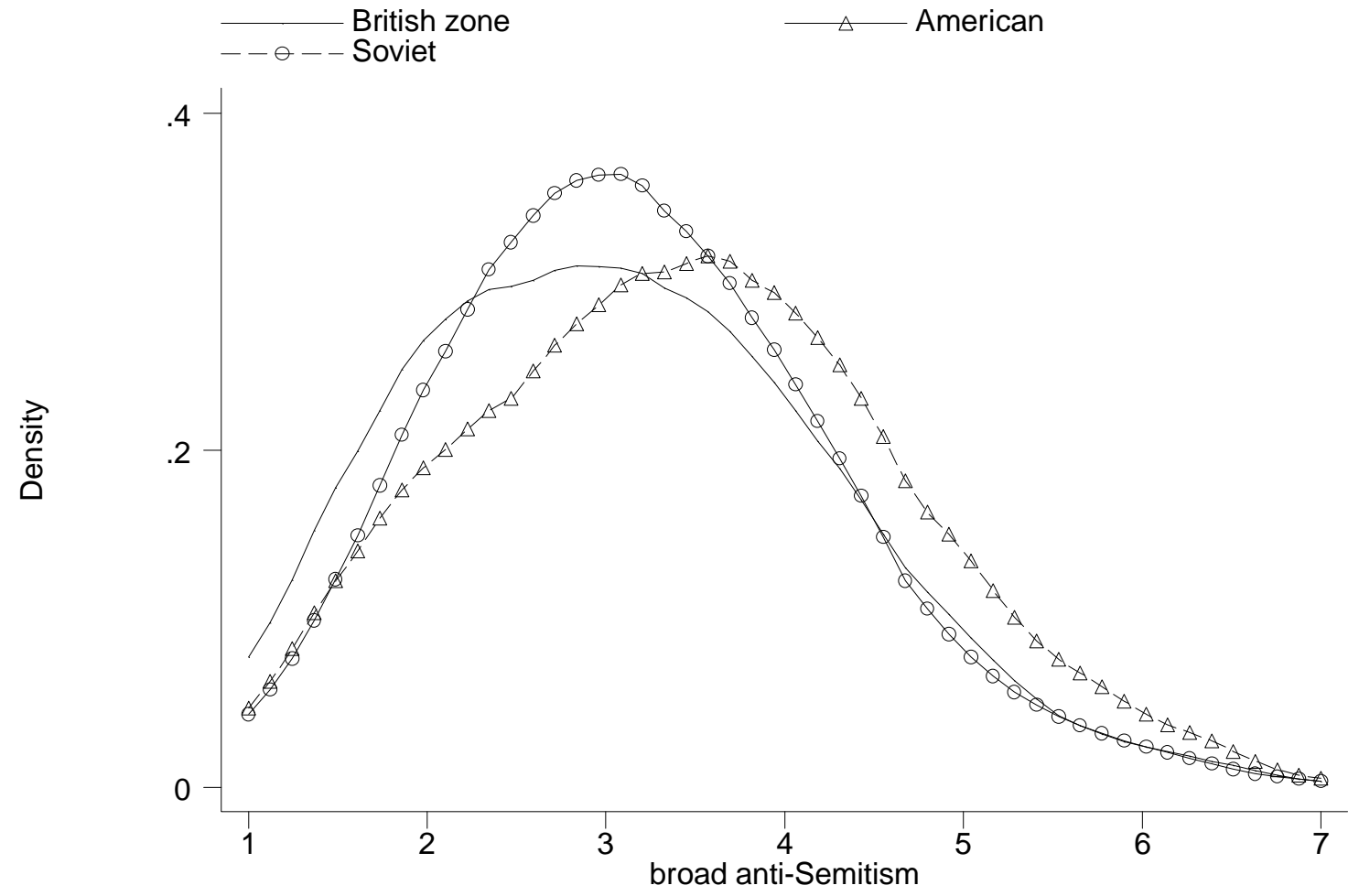

Figure 6: Anti-Semitism in the former British, American, and Soviet zones (broad, scale 1-7) 


\section{TABLES}

Table 1: Overview for main Variables, by Tercile of ALLVOTE

$\begin{array}{lllll}\text { Tercile of } A L L V O T E & 1 & 2 & 3\end{array}$

Indicators for historical anti-Semitism

Anti-Semitic votes, 1890-1912: ASVOTE ${ }^{19 C} \quad .008 \quad .040 \quad .036$

Nazi votes in the 1920s: NSVOTE ${ }^{20 s} \quad .018 \quad .038 \quad 094$

Nazi votes in the 1930s: NSVOTE ${ }^{30 s} \quad .216 \quad .313 \quad .407$

$\underline{\text { ALLBUS survey questions (score 1-7; higher score }=\text { more anti-Semitic) }}$

$\begin{array}{llll}\text { Influence } & 3.17 & 3.26 & 3.37 \\ \text { Shame } & 2.37 & 2.23 & 2.30 \\ \text { Exploit } & 4.21 & 4.20 & 4.32 \\ \text { Responsible } & 2.48 & 2.59 & 2.79 \\ \text { Neighbor } & 3.34 & 3.49 & 3.52 \\ \text { Marriage } & 3.90 & 4.09 & 4.06 \\ \text { Rights } & 2.82 & 2.90 & 3.14\end{array}$

Derived outcome variables for today's anti-Semitism

$\begin{array}{lccc}\text { Broad Anti-Semitism: } A S^{\text {broad }} & 3.15 & 3.24 & 3.33 \\ \text { Committed anti-Semitism: } A S^{\text {comm }} & .040 & .041 & .061 \\ \text { Xenophobia: XENO } & -.168 & .101 & .068\end{array}$

Notes: ASVOTE ${ }^{19 C}$ is the average vote for anti-Semitic parties between 1890 and 1912. NSVOTE ${ }^{20 s}$ is the average vote for the Nazi party in the 1920s (DVFP in 1924 and NSDAP in 1928).

$N_{S V O T E}^{30 s}$ is the average vote for the Nazi party in the 1930s (elections in September 1930 and March 1933). ALLVOTE is the average of (standardized) ASVOTE ${ }^{19 C}, N_{S V O T E}{ }^{20 s}, N_{S V O T E}{ }^{30 s}$. See Section III for details. 
Table 2: Pairwise correlation, anti-Semitism (individual level)

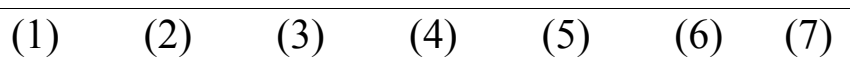
(1) Influence
1
(2) Shame
$.138 * \quad 1$
(3) Exploit
$.520 * .141 * \quad 1$
(4) Responsible $.501 * \quad .180 * \quad .460 * \quad 1$
(5) Neighbor $\quad .280 * \quad .137 * \quad .230 * \quad .267 * \quad 1$
(6) Marriage $\quad .323^{*} .141^{*} \quad .265^{*} \quad .323^{*} \quad .648^{*} 1$

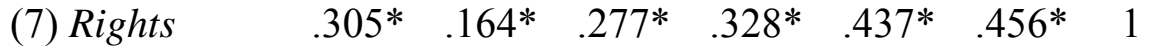

Notes: Correlations reported at the individual respondent level.* significant at the $1 \%$ level.

The number of observations ranges from 6,230 to 6,701 , depending on the number of

respondents for a question.

Table 3: The Consistency of Anti-Semitic Beliefs (at prefecture level, average responses)

\begin{tabular}{lcccc}
\hline Category of $A S^{\text {broad }}$ & \multicolumn{2}{c}{ LOWEST } & \multicolumn{2}{c}{ HIGHEST } \\
& Mittelfranken & Hamburg & Rheinhessen & Niederbayern \\
\hline$A S^{\text {broad }}$ & 2.52 & 2.75 & 3.86 & 4.61 \\
$A S^{\text {comm }}$ & .019 & .058 & .176 & .164 \\
Neighbor & 2.68 & 3.14 & 3.71 & 4.18 \\
Marriage & 3.42 & 3.55 & 4.42 & 5.03 \\
Rights & 1.90 & 2.04 & 3.73 & 4.27 \\
Influence & 2.74 & 2.73 & 3.88 & 4.98 \\
Shame & 2.74 & 2.04 & 3.15 & 3.80 \\
Exploit & 3.61 & 3.45 & 4.66 & 6.05 \\
Responsible & 1.90 & 2.08 & 3.61 & 3.82 \\
Line & .77 & .25 & .87 & .86 \\
\hline Notes: Survey responses based on a scale from 1-7, where higher values indicate more anti-Semitism (see \\
section III.A for detail). The exception is "line", which is either 0 or 1. Line: "One should draw a line beneath \\
Germany's Nazi past."
\end{tabular}


Table 4: Persistence of Anti-Semitism over the $20^{\text {th }}$ century. Baseline Results.

\begin{tabular}{|c|c|c|c|c|c|c|}
\hline Dep. Variable & (1) & $\begin{array}{c}(2) \\
---A S^{\text {broad }} \\
\end{array}$ & (3) & (4) & $\begin{array}{c}\quad(5) \\
---A S^{\text {comm }}--- \\
\end{array}$ & (6) \\
\hline \multicolumn{7}{|c|}{ PANEL A: Full Sample } \\
\hline$A_{S V O T E}^{19 C}$ & $\begin{array}{c}1.199 * * * \\
(.410)\end{array}$ & & & $\begin{array}{c}1.090 * * \\
(.425)\end{array}$ & & \\
\hline$N_{S V O T E}^{20 s}$ & & $\begin{array}{l}.379 \\
(.847)\end{array}$ & & & $\begin{array}{c}1.553 * * \\
(.783)\end{array}$ & \\
\hline$N_{S V O T E}^{30 \mathrm{~s}}$ & & & $\begin{array}{l}.515 \\
(.365)\end{array}$ & & & $\begin{array}{l}.786^{* *} \\
(.366)\end{array}$ \\
\hline $\begin{array}{l}N \\
R^{2}\end{array}$ & $\begin{array}{c}3,797 \\
.008\end{array}$ & $\begin{array}{l}5,791 \\
.000\end{array}$ & $\begin{array}{c}5,806 \\
.002\end{array}$ & 3,955 & 6,047 & 6,062 \\
\hline
\end{tabular}

PANEL B: Only subjects with 2 generations of German ancestors

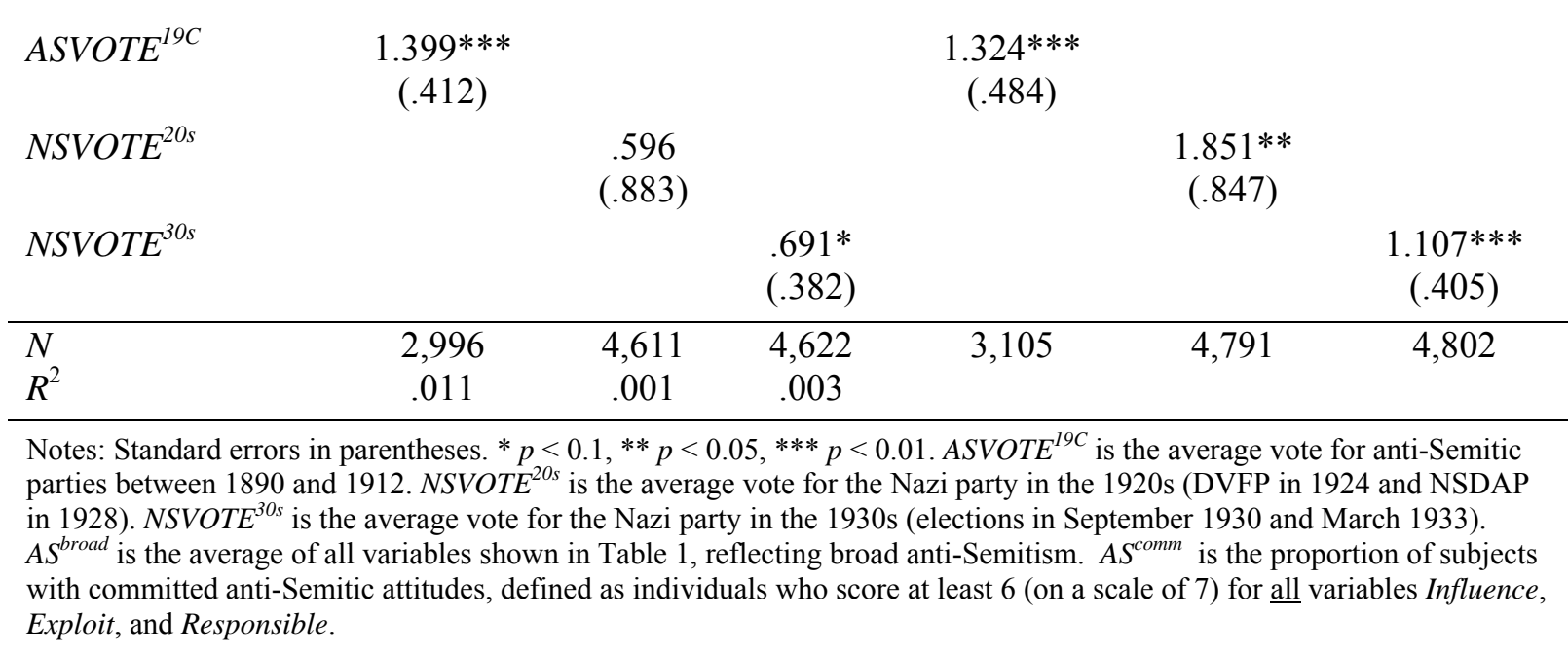


Table 5: Baseline Results with Controls

\begin{tabular}{|c|c|c|c|c|c|c|}
\hline Dep. Var. & (1) & $\begin{array}{c}(2) \\
---A S^{\text {broad }}--- \\
\end{array}$ & (3) & (4) & $\begin{array}{c}\text { (5) } \\
---A S^{\text {comm }} \text {--- } \\
\end{array}$ & (6) \\
\hline ASVOTE $^{19 C}$ & $\begin{array}{c}1.218 * * * \\
(.332)\end{array}$ & & & $\begin{array}{c}1.366^{* * *} \\
(.450)\end{array}$ & & \\
\hline$N_{S V O T E}{ }^{20 \mathrm{~s}}$ & & $\begin{array}{l}.862 \\
(.836)\end{array}$ & & & $\begin{array}{c}2.016^{* * *} \\
(.769)\end{array}$ & \\
\hline$N_{S V O T E}{ }^{30 s}$ & & & $\begin{array}{l}.260 \\
(.378)\end{array}$ & & & $\begin{array}{c}1.057 * * \\
(.428)\end{array}$ \\
\hline High School & $\begin{array}{c}-.453 * * * \\
(.0648)\end{array}$ & $\begin{array}{c}-.421 * * * \\
(.0606)\end{array}$ & $\begin{array}{c}-.419 * * * \\
(.0607)\end{array}$ & $\begin{array}{l}-.236 \\
(.186)\end{array}$ & $\begin{array}{l}-.139 \\
(.133)\end{array}$ & $\begin{array}{l}-.128 \\
(.134)\end{array}$ \\
\hline University & $\begin{array}{c}-.311 * * * \\
(.0668)\end{array}$ & $\begin{array}{c}-.302 * * * \\
(.0609)\end{array}$ & $\begin{array}{c}-.304 * * * \\
(.0609)\end{array}$ & $\begin{array}{l}-.252 \\
(.182)\end{array}$ & $\begin{array}{c}-.417 * * * \\
(.145)\end{array}$ & $\begin{array}{c}-.417 * * * \\
(.146)\end{array}$ \\
\hline Age & $\begin{array}{l}.00884 \\
(.00776)\end{array}$ & $\begin{array}{l}.0166 * * * \\
(.00613)\end{array}$ & $\begin{array}{l}.0167 * * * \\
(.00611)\end{array}$ & $\begin{array}{l}.0355 * * \\
(.0161)\end{array}$ & $\begin{array}{c}.0426 * * * \\
(.0127)\end{array}$ & $\begin{array}{c}.0424 * * * \\
(.0126)\end{array}$ \\
\hline $\mathrm{Age}^{2}$ & $\begin{array}{c}.0000160 \\
(.0000768)\end{array}$ & $\begin{array}{l}-.0000644 \\
(.0000616)\end{array}$ & $\begin{array}{l}-.0000648 \\
(.0000611)\end{array}$ & $\begin{array}{l}-.000222 \\
(.000147)\end{array}$ & $\begin{array}{c}-.000285^{* *} \\
(.000118)\end{array}$ & $\begin{array}{c}-.000288^{* *} \\
(.000117)\end{array}$ \\
\hline $\ln ($ city pop) & $\begin{array}{c}-.0919 * * * \\
(.0181)\end{array}$ & $\begin{array}{c}-.0933 * * * \\
(.0152)\end{array}$ & $\begin{array}{c}-.0897 * * * \\
(.0154)\end{array}$ & $\begin{array}{c}-.0929 * * * \\
(.0269)\end{array}$ & $\begin{array}{c}-.0782 * * * \\
(.0227)\end{array}$ & $\begin{array}{c}-.0629 * * * \\
(.0220)\end{array}$ \\
\hline $\begin{array}{l}\text { Share of } \\
\text { foreigners }\end{array}$ & $\begin{array}{c}2.817 * * * \\
(.666)\end{array}$ & $\begin{array}{c}2.051 * * * \\
(.610)\end{array}$ & $\begin{array}{c}2.063 * * * \\
(.621)\end{array}$ & $\begin{array}{c}4.204 * * * \\
(1.190)\end{array}$ & $\begin{array}{c}2.837 * * * \\
(.906)\end{array}$ & $\begin{array}{c}3.000 * * * \\
(.996)\end{array}$ \\
\hline $\begin{array}{l}N \\
R^{2} \\
\end{array}$ & $\begin{array}{c}2,792 \\
.118 \\
\end{array}$ & $\begin{array}{l}4,375 \\
.096 \\
\end{array}$ & $\begin{array}{c}4,386 \\
.095 \\
\end{array}$ & 2,897 & 4,550 & 4,561 \\
\hline
\end{tabular}

Notes: Standard errors in parentheses. ${ }^{*} p<0.1,{ }^{* *} p<0.05, * * * p<0.01$. ASVOTE ${ }^{19 C}$ is the average vote for anti-Semitic parties between 1890 and 1912. NSVOTE ${ }^{20 s}$ is the average vote for the Nazi party in the 1920s (DVFP in 1924 and NSDAP in 1928). NSVOTE ${ }^{30 s}$ is the average vote for the Nazi party in the 1930s (elections in September 1930 and March 1933). $A S^{\text {broad }}$ is the average of all variables shown in Table 1, reflecting broad anti-Semitism. $A S^{\text {comm }}$ is the proportion of subjects with committed anti-Semitic attitudes, defined as individuals who score at least 6 (on a scale of 7) for all variables Influence, Exploit, and Responsible. All regressions include only subjects with German nationality and at least two generations of German ancestors. 
Table 6: Baseline Results, Controlling for Historical City Characteristics

\begin{tabular}{|c|c|c|c|c|c|c|}
\hline Dep. Var. & (1) & $\begin{array}{c}(2) \\
---A S^{b r o a d}--- \\
\end{array}$ & (3) & (4) & $\begin{array}{c}(5) \\
---A S^{\text {comm }}--- \\
\end{array}$ & (6) \\
\hline$A^{\prime} V_{O T E}^{19 C}$ & $\begin{array}{c}1.301 * * * \\
(.368)\end{array}$ & & & $\begin{array}{c}1.425 * * * \\
(.499)\end{array}$ & & \\
\hline$N_{S V O T E}{ }^{20 s}$ & & $\begin{array}{c}.902 \\
(.823)\end{array}$ & & & $\begin{array}{c}1.788^{* *} \\
(.744)\end{array}$ & \\
\hline$N_{S V O T E}{ }^{30 s}$ & & & $\begin{array}{c}1.065^{* *} \\
(.451)\end{array}$ & & & $\begin{array}{c}1.548^{* * * *} \\
(.536)\end{array}$ \\
\hline \multicolumn{7}{|l|}{1925 Controls: } \\
\hline \%Protestant & $\begin{array}{l}-.00102 \\
(.00187)\end{array}$ & $\begin{array}{l}-.00176 \\
(.00116)\end{array}$ & $\begin{array}{c}-.00350 * * * \\
(.00130)\end{array}$ & $\begin{array}{l}.000738 \\
(.00189)\end{array}$ & $\begin{array}{l}-.000172 \\
(.00145)\end{array}$ & $\begin{array}{l}-.00253 \\
(.00176)\end{array}$ \\
\hline \%Jewish & $\begin{array}{l}.0261 \\
(.0303)\end{array}$ & $\begin{array}{l}.0566 \\
(.0392)\end{array}$ & $\begin{array}{l}.0557 \\
(.0354)\end{array}$ & $\begin{array}{c}.0549 \\
(.0454)\end{array}$ & $\begin{array}{l}.134 * * \\
(.0542)\end{array}$ & $\begin{array}{l}.122 * * \\
(.0505)\end{array}$ \\
\hline $\begin{array}{l}\text { \%Industry } \\
\text { Employment }\end{array}$ & $\begin{array}{l}.00846^{*} \\
(.00460)\end{array}$ & $\begin{array}{l}.0114 * * * \\
(.00382)\end{array}$ & $\begin{array}{l}.0120 * * * \\
(.00389)\end{array}$ & $\begin{array}{l}.00177 \\
(.00647)\end{array}$ & $\begin{array}{l}.0110^{*} \\
(.00595)\end{array}$ & $\begin{array}{l}.0118^{*} \\
(.00630)\end{array}$ \\
\hline $\begin{array}{l}\text { \%Agriculture } \\
\text { Employment }\end{array}$ & $\begin{array}{c}.00624 \\
(.00406)\end{array}$ & $\begin{array}{l}.00711^{* *} \\
(.00339)\end{array}$ & $\begin{array}{l}.00659 * * \\
(.00325)\end{array}$ & $\begin{array}{c}.00265 \\
(.00567)\end{array}$ & $\begin{array}{l}.00624 \\
(.00505)\end{array}$ & $\begin{array}{l}.00463 \\
(.00512)\end{array}$ \\
\hline $\begin{array}{l}\text { \%Self-Emp. } \\
\text { Retail\&Trade }\end{array}$ & $\begin{array}{l}-.00835 \\
(.00692)\end{array}$ & $\begin{array}{l}.00257 \\
(.00526)\end{array}$ & $\begin{array}{l}.00334 \\
(.00530)\end{array}$ & $\begin{array}{c}.00419 \\
(.00726)\end{array}$ & $\begin{array}{l}.00781 \\
(.00700)\end{array}$ & $\begin{array}{l}.00974 \\
(.00705)\end{array}$ \\
\hline$\%$ Blue Collar & $\begin{array}{l}.000524 \\
(.00432)\end{array}$ & $\begin{array}{l}-.00267 \\
(.00368)\end{array}$ & $\begin{array}{l}-.00166 \\
(.00370)\end{array}$ & $\begin{array}{c}.00279 \\
(.00662)\end{array}$ & $\begin{array}{l}-.00405 \\
(.00565)\end{array}$ & $\begin{array}{l}-.00349 \\
(.00570)\end{array}$ \\
\hline Other Controls & yes & yes & yes & yes & yes & yes \\
\hline $\begin{array}{l}N \\
R^{2}\end{array}$ & $\begin{array}{c}2,602 \\
.127\end{array}$ & $\begin{array}{l}4,092 \\
.107 \\
\end{array}$ & $\begin{array}{l}4,092 \\
.111\end{array}$ & 2,701 & 4,258 & 4,258 \\
\hline
\end{tabular}

Notes: Standard errors in parentheses. ${ }^{*} p<0.1, * * p<0.05, * * * p<0.01$. ASVOTE ${ }^{19 C}$ is the average vote for anti-Semitic parties between 1890 and 1912. NSVOTE ${ }^{20 s}$ is the average vote for the Nazi party in the 1920s (DVFP in 1924 and NSDAP in 1928). NSVOTE ${ }^{30 s}$ is the average vote for the Nazi party in the 1930s (elections in September 1930 and March 1933). $A S^{\text {broad }}$ is the average of all variables shown in Table 1, reflecting broad anti-Semitism. $A S^{\text {comm }}$ is the proportion of subjects with committed anti-Semitic attitudes, defined as individuals who score at least 6 (on a scale of 7) for all variables Influence, Exploit, and Responsible. All regressions include only subjects with German nationality and at least two generations of German ancestors. Other controls comprise all control variables used in Table 5. 
Table 7: Consensus in Opinion about Foreigners with Family and Friends
(1)
(2)
(3)
(4)
(5)

(6)

Dep. Var. $---A S^{\text {broad }}$ $---A S^{\text {comm }}---$

\begin{tabular}{lcccccc}
\hline AS Var. & ASVOTE $^{19 C}$ & NSVOTE $^{20 C}$ & NSVOTE $^{30 C}$ & ASVOTE $^{19 C}$ & NSVOTE $^{20 C}$ & NSVOTE $^{30 C}$ \\
\hline \multirow{5}{*}{ AS Variable } & .852 & $3.087 * * *$ & .722 & $2.097^{* *}$ & $3.012^{* *}$ & $1.101^{*}$ \\
& $(.672)$ & $(.780)$ & $(.512)$ & $(.869)$ & $(1.177)$ & $(.620)$ \\
\multirow{2}{*}{ CONTROLS } & yes & yes & yes & yes & yes & yes \\
\hline$N$ & 760 & 1,198 & 1,208 & 812 & 1,290 & 1,300 \\
$R^{2}$ & .354 & .321 & .309 & & & \\
\hline
\end{tabular}

PANEL B: No family consensus about foreigners

\begin{tabular}{lcccccc}
\hline AS Variable & $1.575^{* *}$ & -.528 & $-.889^{*}$ & 1.455 & $-9.464^{*}$ & -1.060 \\
& $(.769)$ & $(1.156)$ & $(.503)$ & $(1.749)$ & $(4.853)$ & $(2.079)$ \\
CONTROLS & yes & yes & yes & yes & yes & yes \\
\hline$N$ & 271 & 414 & 414 & 205 & 317 & 317 \\
& .366 & .343 & .349 & & & \\
\hline
\end{tabular}

PANEL C: Consensus among friends about foreigners

\begin{tabular}{|c|c|c|c|c|c|c|}
\hline AS Variable & $\begin{array}{l}1.063 * \\
(.540)\end{array}$ & $\begin{array}{c}3.114 * * * \\
(.935)\end{array}$ & $\begin{array}{c}.567 \\
(.506)\end{array}$ & $\begin{array}{c}2.064 * * \\
(.987)\end{array}$ & $\begin{array}{c}3.243 * * \\
(1.318)\end{array}$ & $\begin{array}{c}.707 \\
(.713)\end{array}$ \\
\hline CONTROLS & yes & yes & yes & yes & yes & yes \\
\hline$N$ & $\begin{array}{l}711 \\
.395 \\
\end{array}$ & $\begin{array}{l}1,105 \\
.344\end{array}$ & $\begin{array}{c}1,114 \\
.332 \\
\end{array}$ & 756 & 1,189 & 1,198 \\
\hline \multicolumn{7}{|c|}{ PANEL D: No consensus among friends about foreigners } \\
\hline AS Variable & $\begin{array}{l}.793 \\
(.738)\end{array}$ & $\begin{array}{c}.826 \\
(1.004)\end{array}$ & $\begin{array}{l}-.320 \\
(.475)\end{array}$ & $\begin{array}{l}2.187 * \\
(1.220)\end{array}$ & $\begin{array}{c}-6.529 * * \\
(3.173)\end{array}$ & $\begin{array}{c}1.154 \\
(1.325)\end{array}$ \\
\hline CONTROLS & yes & yes & yes & yes & yes & yes \\
\hline$N$ & $\begin{array}{l}313 \\
.243\end{array}$ & $\begin{array}{l}503 \\
.230\end{array}$ & $\begin{array}{l}504 \\
.228\end{array}$ & 258 & 527 & 528 \\
\hline
\end{tabular}

Notes: Standard errors in parentheses. ${ }^{*} p<0.1, * * p<0.05, * * * p<0.01$. ASVOTE ${ }^{19 C}$ is the average vote for anti-Semitic parties between 1890 and 1912. NSVOTE ${ }^{20 s}$ is the average vote for the Nazi party in the 1920s (DVFP in 1924 and NSDAP in 1928). NSVOTE ${ }^{30 s}$ is the average vote for the Nazi party in the 1930s (elections in September 1930 and March 1933).

CONTROLS comprise all control variables used in Table 5, and in addition XENO and Rightwing (see section III.C for details). 
Table 8: Xenophobia of $\mathbf{1}^{\text {st }}$ and $2^{\text {nd }}$ Generation Immigrants

(1) (2) (3) (4)

(4) (5)

(6)

PANEL A: Dep. Var.: Xenophobia of Immigrants (XENOIM)

\begin{tabular}{|c|c|c|c|c|c|c|}
\hline \multirow[b]{2}{*}{$\begin{array}{l}\text { Age groups } \\
\text { incl. }\end{array}$} & \multicolumn{3}{|c|}{$1^{\text {st }}$ Generation Immigrants } & \multicolumn{3}{|c|}{$2^{\text {nd }}$ Generation Immigrants } \\
\hline & all & age $\leq$ med & age $>$ med. & all & age $\leq$ med & age $>$ med. \\
\hline$X E N O G_{c}$ & $\begin{array}{c}.260 \\
(.159)\end{array}$ & $\begin{array}{c}.253 \\
(.215)\end{array}$ & $\begin{array}{c}.264 \\
(.209)\end{array}$ & $\begin{array}{c}.503 * * * \\
(.111)\end{array}$ & $\begin{array}{l}.347 * * \\
(.146)\end{array}$ & $\begin{array}{c}.481^{* * * *} \\
(.160)\end{array}$ \\
\hline$N$ & 323 & 153 & 170 & 290 & 143 & 147 \\
\hline$R^{2}$ & .015 & .013 & .016 & .124 & .062 & .154 \\
\hline
\end{tabular}

Notes: Standard errors in parentheses. $* p<0.1, * * p<0.05, * * * p<0.01 . X^{*} N N O G_{c}$ is the city-level average of the variable $X E N O$ across all Germans (with 2 generations of German ancestors), $A S G^{\text {broad }}$ and $A S G^{\text {comm }}$ are calculated similarly from the variables $A S^{\text {broad }}$ and $A S^{\text {comm }}$. XENOIM is the first principal component of seven variables that measure intolerance towards foreigners; the principal component is calculated only among immigrants (see text for details). CONTROLS comprise all control variables used in Table 5, and in addition Rightwing (see section III.C for details on the construction of variables). 
Table 9: Assimilation of Immigrants and Transmission of Anti-Semitism

\begin{tabular}{|c|c|c|c|c|c|c|}
\hline Dep. Var. & (1) & $\begin{array}{c}(2) \\
---A S^{b r o a d}--- \\
\end{array}$ & (3) & (4) & $\begin{array}{c}(5) \\
---A S^{\text {comm }}--- \\
\end{array}$ & (6) \\
\hline AS Var. & ASVOTE $^{19 C}$ & NSVOTE $E^{20 s}$ & NSVOTE ${ }^{30 s}$ & ASVOTE $^{19 C}$ & NSVOTE ${ }^{20 s}$ & NSVOTE ${ }^{30 \mathrm{~s}}$ \\
\hline \multicolumn{7}{|c|}{ PANEL A: Interaction Effects } \\
\hline AS Variable & $\begin{array}{c}1.134 * * * \\
(.320)\end{array}$ & $\begin{array}{l}-1.363 \\
(1.210)\end{array}$ & $\begin{array}{l}-.314 \\
(.600)\end{array}$ & $\begin{array}{l}.545 \\
(.432)\end{array}$ & $\begin{array}{c}.851 \\
(1.117)\end{array}$ & $\begin{array}{l}.0731 \\
(.760)\end{array}$ \\
\hline $\mathrm{I}^{\text {assimilate }}$ & $\begin{array}{l}.0786 \\
(.0951)\end{array}$ & $\begin{array}{l}-.0951 \\
(.110)\end{array}$ & $\begin{array}{l}-.204 \\
(.293)\end{array}$ & $\begin{array}{l}-.0513 \\
(.136)\end{array}$ & $\begin{array}{l}.0822 \\
(.130)\end{array}$ & $\begin{array}{l}-.538 \\
(.352)\end{array}$ \\
\hline AS $\times \mathrm{I}^{\text {assimilate }}$ & $\begin{array}{c}.294 \\
(.961)\end{array}$ & $\begin{array}{c}4.660 * * * \\
(1.648)\end{array}$ & $\begin{array}{l}1.130 \\
(.937)\end{array}$ & $\begin{array}{c}1.975^{* *} \\
(.856)\end{array}$ & $\begin{array}{c}2.608 \\
(1.681)\end{array}$ & $\begin{array}{c}2.354 * * \\
(1.071)\end{array}$ \\
\hline CONTROLS & yes & yes & yes & yes & yes & yes \\
\hline $\begin{array}{l}N \\
R^{2}\end{array}$ & $\begin{array}{l}1,711 \\
.143 \\
\end{array}$ & $\begin{array}{l}2,577 \\
.136 \\
\end{array}$ & $\begin{array}{c}2,577 \\
.126 \\
\end{array}$ & 1,786 & 2,704 & 2,704 \\
\hline \multicolumn{7}{|c|}{ PANEL B: Implied Coefficients } \\
\hline $\mathrm{I}^{\text {assimilate }}=0$ & $\begin{array}{c}1.134 * * * \\
(.320)\end{array}$ & $\begin{array}{l}-1.363 \\
(1.210)\end{array}$ & $\begin{array}{l}-.314 \\
(.600)\end{array}$ & $\begin{array}{l}.545 \\
(.432)\end{array}$ & $\begin{array}{c}.851 \\
(1.117)\end{array}$ & $\begin{array}{l}.0731 \\
(.760)\end{array}$ \\
\hline $\mathrm{I}^{\text {assimilate }}=1$ & $\begin{array}{l}1.4284 \\
(.9193)\end{array}$ & $\begin{array}{c}3.297 * * * \\
(1.121)\end{array}$ & $\begin{array}{c}.8165 \\
(.7414)\end{array}$ & $\begin{array}{c}2.519 * * * \\
(.8296)\end{array}$ & $\begin{array}{c}3.459 * * * \\
(1.256)\end{array}$ & $\begin{array}{c}2.427 * * * \\
(.8301)\end{array}$ \\
\hline
\end{tabular}

Notes: Standard errors in parentheses. $* p<0.1, * * p<0.05, * * * p<0.01$. ASVOTE ${ }^{19 C}$ is the average vote for anti-Semitic parties between 1890 and 1912. NSVOTE ${ }^{20 s}$ is the average vote for the Nazi party in the 1920s (DVFP in 1924 and NSDAP in 1928). NSVOTE ${ }^{30 s}$ is the average vote for the Nazi party in the 1930s (elections in September 1930 and March 1933). $\mathrm{I}^{\text {assimilate }}$ is an indicator for the degree of assimilation of immigrants; it is a dummy that equals 1 for cities with below-median (percentage) difference between xenophobia of 2 nd generation immigrants and xenophobia of Germans. Note that all $2^{\text {nd }}$ generation immigrants are excluded from the regression. CONTROLS comprise all control variables used in Table 5. 
Table 10: Anti-Semitic Attitudes by Birth Cohort.

(1) (2)

(3)

(4)

(5)

(6)

Dep. Var. $---A S^{\text {broad }}$--$---A S^{\text {comm }}$

\begin{tabular}{|c|c|c|c|c|c|c|}
\hline AS Var. & ASVOTE $^{19 C}$ & $N_{S V O T E}{ }^{20 \mathrm{~s}}$ & $N_{S V O T E}{ }^{30 s}$ & ASVOTE $^{19 C}$ & NSVOTE ${ }^{20 s}$ & $N_{S V O T E}{ }^{30 s}$ \\
\hline \multicolumn{7}{|c|}{ PANEL A: Birth Cohort Dummies } \\
\hline AS Variable & $\begin{array}{c}1.254 * * * \\
(.348)\end{array}$ & $\begin{array}{l}.813 \\
(.775)\end{array}$ & $\begin{array}{c}.242 \\
(.343)\end{array}$ & $\begin{array}{c}1.655^{* * *} \\
(.558)\end{array}$ & $\begin{array}{c}2.698 * * * \\
(.857)\end{array}$ & $\begin{array}{c}1.377 * * * \\
(.492)\end{array}$ \\
\hline \multicolumn{7}{|l|}{ Birth cohort } \\
\hline before 1920 & $\begin{array}{l}-.0483 \\
(.113)\end{array}$ & $\begin{array}{r}-.0389 \\
(.112)\end{array}$ & $\begin{array}{l}-.0416 \\
(.110)\end{array}$ & $\begin{array}{l}-.0178 \\
(.301)\end{array}$ & $\begin{array}{l}.287 \\
(.207)\end{array}$ & $\begin{array}{l}.243 \\
(.207)\end{array}$ \\
\hline 1920-39 & $\begin{array}{l}.162 * * * \\
(.0587)\end{array}$ & $\begin{array}{l}.130 * * * \\
(.0459)\end{array}$ & $\begin{array}{c}.129 * * * \\
(.0460)\end{array}$ & $\begin{array}{l}.483 * * * \\
(.118)\end{array}$ & $\begin{array}{l}.415^{* * *} \\
(.0957)\end{array}$ & $\begin{array}{l}.383 * * * \\
(.0967)\end{array}$ \\
\hline $1940-59$ & $\begin{array}{l}.0668 \\
(.0474)\end{array}$ & $\begin{array}{l}.0890 * * \\
(.0361)\end{array}$ & $\begin{array}{c}.0888^{* *} \\
(.0361)\end{array}$ & $\begin{array}{l}.257 * * \\
(.114)\end{array}$ & $\begin{array}{l}.246 * * * \\
(.0856)\end{array}$ & $\begin{array}{l}.222 * * * \\
(.0843)\end{array}$ \\
\hline CONTROLS & yes & yes & yes & yes & yes & yes \\
\hline $\begin{array}{l}N \\
R^{2}\end{array}$ & $\begin{array}{c}2,562 \\
.325\end{array}$ & $\begin{array}{c}4,012 \\
.305\end{array}$ & $\begin{array}{c}4,022 \\
.306\end{array}$ & 2,785 & 4,326 & 4,336 \\
\hline
\end{tabular}

PANEL B: Exclude Individuals Born in 1920-39

\begin{tabular}{lcccccc}
\hline AS Variable & $.900^{* *}$ & 1.182 & .160 & $1.866^{* * *}$ & $3.531^{* * *}$ & $1.303^{* *}$ \\
& $(.390)$ & $(.773)$ & $(.344)$ & $(.586)$ & $(.911)$ & $(.636)$ \\
CONTROLS & yes & yes & yes & yes & yes & yes \\
\hline$N$ & 1,881 & 2,995 & 3,004 & 1,929 & 3,075 & 3,084 \\
$R^{2}$ & .326 & .319 & .318 & & & \\
\hline
\end{tabular}

Notes: Standard errors in parentheses. ${ }^{*} p<0.1,{ }^{* *} p<0.05, * * * p<0.01$. ASVOTE ${ }^{19 C}$ is the average vote for anti-Semitic parties between 1890 and 1912. NSVOTE ${ }^{20 s}$ is the average vote for the Nazi party in the 1920s (DVFP in 1924 and NSDAP in 1928). NSVOTE ${ }^{30 s}$ is the average vote for the Nazi party in the 1930s (elections in September 1930 and March 1933). CONTROLS comprise all control variables used in Table 5, and in addition XENO and Rightwing (see section III.C for details). 
Table 11: Where was Youth Growing up under Hitler Influenced the Most?

(1) (2)

--- $A S^{\text {broad }}$

(3)

(4)

(5)

$---A S^{\text {comm }}$

(6)

\begin{tabular}{lcccccc} 
Dep. Var. & \multicolumn{3}{c}{--- AS $^{\text {comm }}$--- } \\
\hline Vote Var. & CenLeft20s & CenLeft30s & CenRight20s & CenLeft20s & CenLeft30s & CenRight20s \\
\hline Vote Variable & .206 & .340 & $-.879^{* *}$ & .287 & .305 & $-.988^{*}$ \\
& $(.466)$ & $(.515)$ & $(.388)$ & $(.623)$ & $.664)$ & $(.548)$ \\
Vote $\times \mathrm{I}^{1920-39}$ & $-1.278^{* *}$ & $-1.314^{* *}$ & $1.129^{* *}$ & $-1.734^{*}$ & -1.571 & $1.854^{* *}$ \\
& $(.567)$ & $(.569)$ & $(.495)$ & $(.936)$ & $(1.010)$ & $(.732)$ \\
$\mathrm{I}^{1920-39}$ & $.577^{* * *}$ & $.566^{* * *}$ & .133 & $.673^{* * *}$ & $.624^{* * *}$ & .0324 \\
& $(.110)$ & $(.105)$ & $(.101)$ & $(.167)$ & $(.168)$ & $(.167)$ \\
CONTROLS & yes & yes & yes & yes & yes & yes \\
\hline$N$ & 4,380 & 4,380 & 4,380 & 4,555 & 4,555 & 4,555 \\
$R^{2}$ & .097 & .097 & .099 & & & \\
\hline
\end{tabular}

Notes: Standard errors in parentheses. $* p<0.1, * * p<0.05, * * * p<0.01$. CenLeft20s is the average vote share of left (KPD Communist Party) and center-left (SPD - Social Democratic) parties in the 1924 and 1928 elections. CenLeft30s is the same for the 1930 and 1933 elections. CenRight20s is the average vote share of the right-wing (DNVP - German National People's Party), the center-right DVP (German People's Party), and the center party Zentrum (Centre Party) in the 1924 and 1928 elections. I $^{1920-39}$ is an indicator that equals 1 for individuals that were born between 1920 and 1939. CONTROLS comprise all control variables used in Table 5 . 
Table 12: Level effects of Occupation Zones

\begin{tabular}{|c|c|c|c|c|c|c|}
\hline Dep. Var. & $\overline{(1)}$ & $\begin{array}{c}(2) \\
---A S^{\text {broad }}--- \\
\end{array}$ & (3) & (4) & $\begin{array}{c}(5) \\
---A S^{\text {comm }} \text {--- }\end{array}$ & 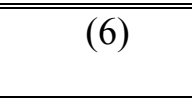 \\
\hline \multicolumn{7}{|c|}{ PANEL A: Without historical controls } \\
\hline \multicolumn{7}{|c|}{ Occupation Zone } \\
\hline French & & $\begin{array}{l}.127 \\
(.145)\end{array}$ & & & $\begin{array}{l}.0846 \\
(.189)\end{array}$ & \\
\hline British & & $\begin{array}{c}-.351 * * * \\
(.0911)\end{array}$ & & & $\begin{array}{c}-.290 * * * \\
(.106)\end{array}$ & \\
\hline Soviet & & $\begin{array}{c}-.330^{* * *} \\
(.115)\end{array}$ & & & $\begin{array}{c}-.508 * * * \\
(.133)\end{array}$ & \\
\hline CONTROLS & & yes & & & yes & \\
\hline $\begin{array}{l}N \\
R^{2}\end{array}$ & & $\begin{array}{c}4,294 \\
.108\end{array}$ & & & 4,461 & \\
\hline \multicolumn{7}{|c|}{ PANEL B: Controlling for historical anti-Semitic votes } \\
\hline AS Var. & ASVOTE $^{19 C}$ & NSVOTE ${ }^{20 s}$ & NSVOTE ${ }^{30 s}$ & ASVOTE $^{19 C}$ & NSVOTE ${ }^{20 s}$ & NSVOTE ${ }^{30 s}$ \\
\hline AS Variable & $\begin{array}{l}.906 * * \\
(.371)\end{array}$ & $\begin{array}{c}.277 \\
(.840)\end{array}$ & $\begin{array}{l}.244 \\
(.347)\end{array}$ & $\begin{array}{c}1.095 * * \\
(.447)\end{array}$ & $\begin{array}{c}1.605 * * \\
(.814)\end{array}$ & $\begin{array}{c}1.034 * * * \\
(.393)\end{array}$ \\
\hline \multicolumn{7}{|c|}{ Occupation Zone } \\
\hline French & $\begin{array}{l}.163 \\
(.212)\end{array}$ & $\begin{array}{l}.136 \\
(.149)\end{array}$ & $\begin{array}{l}.129 \\
(.144)\end{array}$ & $\begin{array}{l}-.0579 \\
(.148)\end{array}$ & $\begin{array}{l}.126 \\
(.187)\end{array}$ & $\begin{array}{l}.0900 \\
(.179)\end{array}$ \\
\hline British & $\begin{array}{l}-.243 * * \\
(.107)\end{array}$ & $\begin{array}{c}-.338 * * * \\
(.0895)\end{array}$ & $\begin{array}{c}-.349 * * * \\
(.0910)\end{array}$ & $\begin{array}{l}-.132 \\
(.128)\end{array}$ & $\begin{array}{l}-.210^{*} \\
(.109)\end{array}$ & $\begin{array}{c}-.293 * * * \\
(.104)\end{array}$ \\
\hline Soviet & $\begin{array}{l}-.204 \\
(.139)\end{array}$ & $\begin{array}{c}-.319 * * * \\
(.113)\end{array}$ & $\begin{array}{c}-.330 * * * \\
(.116)\end{array}$ & $\begin{array}{l}-.249 \\
(.163)\end{array}$ & $\begin{array}{c}-.433 * * * \\
(.138)\end{array}$ & $\begin{array}{c}-.497 * * * \\
(.129)\end{array}$ \\
\hline CONTROLS & yes & yes & yes & yes & yes & yes \\
\hline$N$ & 2,700 & 4,283 & 4,294 & 2,797 & 4,450 & 4,461 \\
\hline$R^{2}$ & .122 & .108 & .109 & & & \\
\hline
\end{tabular}

Notes: Standard errors in parentheses. ${ }^{*} p<0.1, * * p<0.05, * * * p<0.01$. ASVOTE ${ }^{19 C}$ is the average vote for anti-Semitic parties between 1890 and 1912. NSVOTE ${ }^{20 s}$ is the average vote for the Nazi party in the 1920s (DVFP in 1924 and NSDAP in 1928). NSVOTE ${ }^{30 s}$ is the average vote for the Nazi party in the 1930s (elections in September 1930 and March 1933). CONTROLS comprise all control variables used in Table 5. 
Table 13: Results for Occupation Zones $-100 \mathrm{~km}$ Border Sample

\begin{tabular}{|c|c|c|c|c|c|c|}
\hline Dep. Var. & $\overline{~(1)}$ & $\begin{array}{c}(2) \\
---A S^{\text {broad }} \text {--- }\end{array}$ & (3) & $\overline{(4)}$ & $\begin{array}{c}(5) \\
---A S^{\text {comm }}--- \\
\end{array}$ & (6) \\
\hline AS Var. & ASVOTE $^{19 C}$ & NSVOTE $^{20 s}$ & NSVOTE $^{30 \mathrm{~s}}$ & ASVOTE $^{19 C}$ & NSVOTE $^{20 s}$ & $N_{S V O T E^{30 s}}$ \\
\hline AS Variable & $\begin{array}{c}1.497 * * * \\
(.470)\end{array}$ & $\begin{array}{c}.672 \\
(1.375)\end{array}$ & $\begin{array}{l}.685 \\
(.525)\end{array}$ & $\begin{array}{l}1.106^{*} \\
(.594)\end{array}$ & $\begin{array}{l}1.014 \\
(2.192)\end{array}$ & $\begin{array}{c}1.254 * * * \\
(.480)\end{array}$ \\
\hline British & $\begin{array}{l}-.132 \\
(.147)\end{array}$ & $\begin{array}{c}-.375^{* * *} \\
(.125)\end{array}$ & $\begin{array}{c}-.349 * * * \\
(.118)\end{array}$ & $\begin{array}{l}-.202 \\
(.182)\end{array}$ & $\begin{array}{c}-.380^{* *} \\
(.153)\end{array}$ & $\begin{array}{c}-.333^{* *} \\
(.150)\end{array}$ \\
\hline CONTROLS & yes & yes & yes & yes & yes & yes \\
\hline $\begin{array}{l}N \\
R^{2} \\
\end{array}$ & $\begin{array}{l}825 \\
.184\end{array}$ & $\begin{array}{l}1,195 \\
.135 \\
\end{array}$ & $\begin{array}{l}1,206 \\
.139 \\
\end{array}$ & 1,281 & 1,270 & 1,281 \\
\hline
\end{tabular}

Notes: Standard errors in parentheses. $* p<0.1, * * p<0.05, * * * p<0.01$. ASVOTE ${ }^{19 C}$ is the average vote for anti-Semitic parties between 1890 and 1912. NSVOTE ${ }^{20 s}$ is the average vote for the Nazi party in the 1920s (DVFP in 1924 and NSDAP in 1928). NSVOTE ${ }^{30 s}$ is the average vote for the Nazi party in the 1930s (elections in September 1930 and March 1933). CONTROLS comprise all control variables used in Table 5. 
Table 14: Anti-Semitism and Xenophobia in Main Results

\begin{tabular}{|c|c|c|c|c|c|c|}
\hline & (1) & (2) & (3) & (4) & (5) & (6) \\
\hline Dep. Variable & & --- $A S^{\text {broad }}$ & & & --- $A S^{\text {comm }}$ & \\
\hline ASVOTE $^{19 C}$ & $\begin{array}{c}1.246 * * * \\
(.348)\end{array}$ & & & $\begin{array}{c}1.619 * * * \\
(.554)\end{array}$ & & \\
\hline NSVOTE ${ }^{20 s}$ & & $\begin{array}{c}.781 \\
(.764)\end{array}$ & & & $\begin{array}{c}2.546^{* * *} \\
(.798)\end{array}$ & \\
\hline NSVOTE $^{30 \mathrm{~s}}$ & & & $\begin{array}{l}.234 \\
(.339)\end{array}$ & & & $\begin{array}{c}1.341 * * * \\
(.468)\end{array}$ \\
\hline XENO & $\begin{array}{l}.551 * * * \\
(.0276)\end{array}$ & $\begin{array}{l}.566^{* * *} \\
(.0225)\end{array}$ & $\begin{array}{l}.567 * * * \\
(.0226)\end{array}$ & $\begin{array}{l}.410 * * * \\
(.0660)\end{array}$ & $\begin{array}{l}.411 * * * \\
(.0492)\end{array}$ & $\begin{array}{l}.404 * * * \\
(.0470)\end{array}$ \\
\hline Rightwing & $\begin{array}{c}.289 * * * \\
(.0708)\end{array}$ & $\begin{array}{l}.284 * * * \\
(.0574)\end{array}$ & $\begin{array}{l}.285 * * * \\
(.0574)\end{array}$ & $\begin{array}{c}.133 \\
(.143)\end{array}$ & $\begin{array}{l}.182^{*} \\
(.108)\end{array}$ & $\begin{array}{l}.197^{*} \\
(.108)\end{array}$ \\
\hline CONTROLS & yes & yes & yes & yes & yes & yes \\
\hline $\begin{array}{l}N \\
R^{2}\end{array}$ & $\begin{array}{c}2,560 \\
.324\end{array}$ & $\begin{array}{c}4,008 \\
.306\end{array}$ & $\begin{array}{c}4,018 \\
.306\end{array}$ & 2,626 & 4,119 & 4,129 \\
\hline
\end{tabular}

Notes: Standard errors in parentheses. ${ }^{*} p<0.1,{ }^{* *} p<0.05, * * * p<0.01$. ASVOTE ${ }^{19 C}$ is the average vote for anti-Semitic parties between 1890 and 1912. NSVOTE ${ }^{20 s}$ is the average vote for the Nazi party in the 1920s (DVFP in 1924 and NSDAP in 1928). NSVOTE ${ }^{30 s}$ is the average vote for the Nazi party in the 1930s (elections in September 1930 and March 1933). $X E N O$ is the first principal component of seven variables that measure intolerance towards foreigners (see Section III for details). CONTROLS comprise all control variables used in Table 5. All regressions include only subjects with German nationality and at least two generations of German ancestors. 
Table 15: Results for Anti-Semitic Party Electoral Results in 1890-1912

\begin{tabular}{|c|c|c|c|c|c|c|}
\hline & (1) & (2) & (3) & (4) & (5) & (6) \\
\hline AS Var. & ASVOTE $^{1890}$ & ASVOTE $^{1893}$ & ASVOTE $^{1898}$ & ASVOTE $^{1903}$ & ASVOTE ${ }^{1907}$ & ASVOTE $^{1912}$ \\
\hline \multicolumn{7}{|c|}{ PANEL A: Dependent Variable: $A S^{\text {broad }}$} \\
\hline AS Variable & $\begin{array}{c}1.979 * * * \\
(.540)\end{array}$ & $\begin{array}{c}1.024 * * * \\
(.383)\end{array}$ & $\begin{array}{c}1.030 * * * \\
(.296)\end{array}$ & $\begin{array}{c}1.346 * * * \\
(.352)\end{array}$ & $\begin{array}{c}1.828 * * * \\
(.588)\end{array}$ & $\begin{array}{l}.975 * * \\
(.418)\end{array}$ \\
\hline CONTROLS & yes & yes & yes & yes & yes & yes \\
\hline$N$ & 661 & 1,909 & 1,779 & 1,235 & 651 & 860 \\
\hline$R^{2}$ & .211 & .127 & .125 & .178 & .232 & .161 \\
\hline \multicolumn{7}{|c|}{ PANEL B: Dependent Variable: $A S^{\text {comm }}$} \\
\hline AS Variable & $\begin{array}{c}1.674 * * * \\
(.581)\end{array}$ & $\begin{array}{c}1.116^{* *} \\
(.445)\end{array}$ & $\begin{array}{c}1.188 * * * \\
(.396)\end{array}$ & $\begin{array}{c}1.456 * * * \\
(.457)\end{array}$ & $\begin{array}{c}1.239^{* *} \\
(.563)\end{array}$ & $\begin{array}{c}1.421 * * \\
(.646)\end{array}$ \\
\hline CONTROLS & yes & yes & yes & yes & yes & yes \\
\hline$N$ & 518 & 1,982 & 1,836 & 1,285 & 585 & 753 \\
\hline
\end{tabular}

Notes: Standard errors in parentheses. $* p<0.1, * * p<0.05, * * * p<0.01$. ASVOTE ${ }^{19 C}$ is the average vote for anti-Semitic parties between 1890 and 1912. NSVOTE ${ }^{20 s}$ is the average vote for the Nazi party in the 1920s (DVFP in 1924 and NSDAP in 1928). NSVOTE ${ }^{30 s}$ is the average vote for the Nazi party in the 1930s (elections in September 1930 and March 1933).

CONTROLS comprise all control variables used in Table 5. All regressions include only subjects with German nationality and at least two generations of German ancestors.

Table 16: Results for Nazi Party Electoral Results in 1924-33

$\begin{array}{llll}(1) & (2) & \text { (3) }\end{array}$

\begin{tabular}{lcccc} 
AS Var. & $D V F P^{1924}$ & $N^{2} D A P^{1928}$ & $N^{2} D A P^{1930}$ & $N S D A P^{1933}$ \\
& PANEL A: Dependent Variable: $A S^{\text {broad }}$ & \\
\hline AS Variable & .656 & .640 & .322 & .152 \\
& $(.577)$ & $(.864)$ & $(.391)$ & $(.312)$ \\
CONTROLS & yes & yes & yes & yes \\
& & & & \\
\hline$N$ & 4,375 & 4,375 & 4,386 & 4,386 \\
$R^{2}$ & .096 & .095 & .095 & .094 \\
\hline
\end{tabular}

PANEL B: Dependent Variable: $A S^{\text {comm }}$

\begin{tabular}{lcccc}
\hline AS Variable & $1.417^{* *}$ & $1.821^{* *}$ & $1.121^{* *}$ & $.657^{*}$ \\
& $(.656)$ & $(.767)$ & $(.472)$ & $(.363)$ \\
CONTROLS & yes & yes & yes & yes \\
\hline$N$ & 4,550 & 4,550 & 4,561 & 4,647 \\
\hline
\end{tabular}

Notes: Standard errors in parentheses. $* p<0.1, * * p<0.05, * * * p<0.01$. ASVOTE ${ }^{19 C}$ is the average vote for anti-Semitic parties between 1890 and 1912. NSVOTE ${ }^{20 C}$ is the average vote for the Nazi party in the 1920s (DVFP in 1924 and NSDAP in 1928). $A L L V O T E$ is the average of ASVOTE ${ }^{19 C}$ and NSVOTE ${ }^{20 C}$. All regressions include only subjects with German nationality and at least two generations of German ancestors. 
Table 17: Mass Population Inflow and Persistence: Expellees

\begin{tabular}{|c|c|c|c|c|c|c|}
\hline Dep. Var. & (1) & $\begin{array}{c}(2) \\
---A S^{b r o a d}--- \\
\end{array}$ & (3) & (4) & $\begin{array}{c}(5) \\
---A S^{\text {comm }}--- \\
\end{array}$ & (6) \\
\hline AS Var. & ASVOTE $^{19 C}$ & NSVOTE $E^{20 s}$ & NSVOTE $E^{30 s}$ & ASVOTE $^{19 C}$ & NSVOTE ${ }^{20 s}$ & NSVOTE ${ }^{30 \mathrm{~s}}$ \\
\hline \multicolumn{7}{|c|}{ PANEL A: Interaction with Share of Expellees in 1956 Population above Median } \\
\hline AS Variable & $\begin{array}{l}1.178 \\
(1.003)\end{array}$ & $\begin{array}{l}1.365 \\
(1.760)\end{array}$ & $\begin{array}{c}1.776^{* * * *} \\
(.615)\end{array}$ & $\begin{array}{c}2.582 * * * \\
(.757)\end{array}$ & $\begin{array}{c}6.450 * * * \\
(1.676)\end{array}$ & $\begin{array}{c}2.974 * * * \\
(.799)\end{array}$ \\
\hline $\mathrm{I}^{\% \text { Exp }>\text { med }}$ & $\begin{array}{l}-.139 \\
(.0920)\end{array}$ & $\begin{array}{l}-.115 \\
(.0951)\end{array}$ & $\begin{array}{l}.480 * * \\
(.218)\end{array}$ & $\begin{array}{l}-.135 \\
(.120)\end{array}$ & $\begin{array}{l}-.00300 \\
(.124)\end{array}$ & $\begin{array}{c}.411 \\
(.295)\end{array}$ \\
\hline AS $\times I^{\% \text { Exp>med }}$ & $\begin{array}{l}-.224 \\
(1.013)\end{array}$ & $\begin{array}{l}-.967 \\
(2.119)\end{array}$ & $\begin{array}{c}-2.209^{* * * *} \\
(.767)\end{array}$ & $\begin{array}{c}-1.480^{*} \\
(.852)\end{array}$ & $\begin{array}{c}-5.496^{* * * *} \\
(1.996)\end{array}$ & $\begin{array}{c}-2.268 * * \\
(.983)\end{array}$ \\
\hline CONTROLS & yes & yes & yes & yes & yes & yes \\
\hline $\begin{array}{l}N \\
R^{2}\end{array}$ & $\begin{array}{l}1,711 \\
.151\end{array}$ & $\begin{array}{l}2,577 \\
.122 \\
\end{array}$ & $\begin{array}{c}2,577 \\
.125 \\
\end{array}$ & 1,786 & 2,704 & 2,704 \\
\hline \multicolumn{7}{|c|}{ PANEL B: Implied Coefficients } \\
\hline $\mathrm{I}^{\% \mathrm{Exp}>\operatorname{med}}=0$ & $\begin{array}{l}1.178 \\
(1.003)\end{array}$ & $\begin{array}{c}1.365 \\
(1.760)\end{array}$ & $\begin{array}{c}1.776 * * * \\
(.615)\end{array}$ & $\begin{array}{c}2.582 * * * \\
(.757)\end{array}$ & $\begin{array}{c}6.450 * * * \\
(1.676)\end{array}$ & $\begin{array}{c}2.974 * * * \\
(.799)\end{array}$ \\
\hline $\mathrm{I}^{\mathrm{Expp}>\operatorname{med}}=1$ & $\begin{array}{c}.953 \\
(.259)\end{array}$ & $\begin{array}{l}.3980 \\
(1.069)\end{array}$ & $\begin{array}{l}-.4330 \\
(.4350)\end{array}$ & $\begin{array}{l}1.101 \\
(.4942)\end{array}$ & $\begin{array}{l}.9540 \\
(.9047)\end{array}$ & $\begin{array}{l}.7061 \\
(.5061)\end{array}$ \\
\hline
\end{tabular}

Notes: Standard errors in parentheses. $* p<0.1, * * p<0.05, * * * p<0.01$. ASVOTE ${ }^{19 C}$ is the average vote for anti-Semitic parties between 1890 and 1912. NSVOTE ${ }^{20 s}$ is the average vote for the Nazi party in the 1920s (DVFP in 1924 and NSDAP in 1928). NSVOTE ${ }^{30 s}$ is the average vote for the Nazi party in the 1930s (elections in September 1930 and March 1933). CONTROLS comprise all control variables used in Table 5, and in addition XENO - the first principal component of seven variables that measure intolerance towards foreigners (see text for details). $\mathrm{I}^{\% \mathrm{Exp}>\mathrm{med}}$ is an indicator that equals 1 if the share of expellees from Eastern German territories in a city is larger than the median. 
Table 18: Bomb Destruction and Anti-Semitic Sentiment

(1) (2)

Dep. Var.

\begin{tabular}{|c|c|c|c|c|c|c|}
\hline \multirow{2}{*}{$\begin{array}{l}\text { Dep. var. } \\
\text { AS Var. }\end{array}$} & & \\
\hline & ASVOTE $^{19 C}$ & $N_{S V O T E}^{20 C}$ & NSVOTE $^{30 C}$ & ASVOTE $^{19 C}$ & NSVOTE ${ }^{20 C}$ & NSVOTE ${ }^{30 C}$ \\
\hline \multicolumn{7}{|c|}{ Panel A: Rubble } \\
\hline AS Variable & $\begin{array}{c}1.431 * * * \\
(.359)\end{array}$ & $\begin{array}{l}.606 \\
(.924)\end{array}$ & $\begin{array}{l}.288 \\
(.420)\end{array}$ & $\begin{array}{c}1.585 * * * \\
(.496)\end{array}$ & $\begin{array}{c}2.053 * * * \\
(.795)\end{array}$ & $\begin{array}{c}1.042 * * \\
(.453)\end{array}$ \\
\hline $\ln (1+$ Rubble $)$ & $\begin{array}{l}.00326 \\
(.0667)\end{array}$ & $\begin{array}{l}-.00775 \\
(.0667)\end{array}$ & $\begin{array}{l}-.0118 \\
(.0653)\end{array}$ & $\begin{array}{c}.0166 \\
(.0937)\end{array}$ & $\begin{array}{l}.0939 \\
(.0896)\end{array}$ & $\begin{array}{c}.0759 \\
(.0966)\end{array}$ \\
\hline $\ln ($ pop 1939) & $\begin{array}{l}-.0736 \\
(.0528)\end{array}$ & $\begin{array}{l}-.0372 \\
(.0440)\end{array}$ & $\begin{array}{l}-.0346 \\
(.0441)\end{array}$ & $\begin{array}{l}-.0539 \\
(.0635)\end{array}$ & $\begin{array}{l}-.0698 \\
(.0545)\end{array}$ & $\begin{array}{l}-.0530 \\
(.0601)\end{array}$ \\
\hline CONTROLS & yes & yes & yes & yes & yes & yes \\
\hline $\begin{array}{l}N \\
R^{2}\end{array}$ & $\begin{array}{c}2,123 \\
.147 \\
\end{array}$ & $\begin{array}{c}3,320 \\
.107\end{array}$ & $\begin{array}{c}3,331 \\
.107 \\
\end{array}$ & 2,214 & 3,464 & 3,475 \\
\hline \multicolumn{7}{|c|}{ Panel B: Destroyed Housing Stock } \\
\hline AS Variable & $\begin{array}{l}1.281^{*} \\
(.647)\end{array}$ & $\begin{array}{c}.686 \\
(1.467)\end{array}$ & $\begin{array}{l}1.040 \\
(1.259)\end{array}$ & $\begin{array}{l}-1.908 \\
(1.848)\end{array}$ & $\begin{array}{c}3.068^{* *} \\
(1.478)\end{array}$ & $\begin{array}{l}3.143^{*} \\
(1.757)\end{array}$ \\
\hline $\begin{array}{l}\text { \%Destroyed } \\
\text { Flats }\end{array}$ & $\begin{array}{l}-.00312 \\
(.00203)\end{array}$ & $\begin{array}{l}-.00107 \\
(.00265)\end{array}$ & $\begin{array}{l}-.000843 \\
(.00254)\end{array}$ & $\begin{array}{l}-.000430 \\
(.00399)\end{array}$ & $\begin{array}{l}.00433 \\
(.00405)\end{array}$ & $\begin{array}{c}.00471 \\
(.00432)\end{array}$ \\
\hline $\ln ($ pop 1939) & $\begin{array}{l}.381 * * \\
(.169)\end{array}$ & $\begin{array}{l}.445^{* *} \\
(.178)\end{array}$ & $\begin{array}{l}.380 * * \\
(.175)\end{array}$ & $\begin{array}{l}-.222 \\
(.221)\end{array}$ & $\begin{array}{c}.401 \\
(.265)\end{array}$ & $\begin{array}{l}.251 \\
(.261)\end{array}$ \\
\hline CONTROLS & yes & yes & yes & yes & yes & yes \\
\hline $\begin{array}{l}N \\
R^{2} \\
\end{array}$ & $\begin{array}{l}1208 \\
.124 \\
\end{array}$ & $\begin{array}{l}1395 \\
.122 \\
\end{array}$ & $\begin{array}{l}1406 \\
.123 \\
\end{array}$ & 1252 & 1451 & 1462 \\
\hline
\end{tabular}

Notes: Standard errors in parentheses. $* p<0.1, * * p<0.05, * * * p<0.01$. ASVOTE ${ }^{19 C}$ is the average vote for anti-Semitic parties between 1890 and 1912. NSVOTE ${ }^{20 s}$ is the average vote for the Nazi party in the 1920s (DVFP in 1924 and NSDAP in 1928). NSVOTE ${ }^{30 s}$ is the average vote for the Nazi party in the 1930s (elections in September 1930 and March 1933).

$\mathrm{I}^{\% \text { Expellees }>\text { med }}$ is an indicator that equals 1 if the share of expellees from Eastern German territories in a city is larger than the median. Rubble measures the rubble (in cubic meters per inhabitant) from the bomb destruction of German cities after WWII. CONTROLS comprise all control variables used in Table 5. 
Table 19: City Level Regressions and Geographic Matching Estimation

\begin{tabular}{lcccccc}
\hline Dep. Var. & $(1)$ & $\begin{array}{c}(2) \\
\text { broad }\end{array}$ & $(3)$ & $(4)$ & $\begin{array}{c}(5) \\
\text { c--- }\end{array} S^{\text {comm }}---$ & $(6)$ \\
\hline AS Var. & ASVOTE $^{19 C}$ & NSVOTE $^{20 s}$ & NSVOTE $^{30 \text { s }}$ & ASVOTE $^{19 C}$ & NSVOTE $^{20 s}$ & NSVOTE \\
\hline \multicolumn{7}{c}{ PANEL A: OLS Regressions at the City Level } \\
\hline AS Variable & $1.249^{* * *}$ & 1.037 & .197 & $.154^{* *}$ & $.271^{*}$ & $.114^{*}$ \\
& $(.355)$ & $(.830)$ & $(.392)$ & $(.0734)$ & $(.151)$ & $(.0580)$ \\
CONTROLS & yes & yes & yes & yes & yes & yes \\
\hline$N$ & 153 & 254 & 255 & 153 & 254 & 255 \\
$R^{2}$ & .303 & .182 & .172 & .145 & .071 & .054 \\
\hline
\end{tabular}

PANEL B: Poisson ML Regressions at the City Level

\begin{tabular}{lcccccc}
\hline AS Variable & $.357^{* * *}$ & .311 & .0573 & $2.172^{* * *}$ & $3.860^{* * *}$ & $1.984^{* *}$ \\
& $(.0950)$ & $(.237)$ & $(.116)$ & $(.781)$ & $(1.373)$ & $(.818)$ \\
CONTROLS & yes & yes & yes & yes & yes & yes \\
$N$ & 153 & 254 & 255 & 153 & 254 & 255 \\
\hline
\end{tabular}

PANEL C: Matching Estimation based on Controls

\begin{tabular}{|c|c|c|c|c|c|c|}
\hline AS Variable & $\begin{array}{c}.0619 \\
(.0980)\end{array}$ & $\begin{array}{l}.233 * * \\
(.0946)\end{array}$ & $\begin{array}{c}-.103 \\
(.0719)\end{array}$ & $\begin{array}{l}.0165^{* *} \\
(.00743)\end{array}$ & $\begin{array}{l}.0301 * * * \\
(.00812)\end{array}$ & $\begin{array}{c}.0123 \\
(.00871)\end{array}$ \\
\hline CONTROLS & {$[\mathrm{mv}]$} & {$[\mathrm{mv}]$} & {$[\mathrm{mv}]$} & {$[\mathrm{mv}]$} & {$[\mathrm{mv}]$} & {$[\mathrm{mv}]$} \\
\hline$N$ & 153 & 254 & 255 & 153 & 254 & 255 \\
\hline \multicolumn{7}{|c|}{ PANEL D: Matching Estimation based on Controls and Geography } \\
\hline AS Variable & $\begin{array}{c}-.00254 \\
(.0515)\end{array}$ & $\begin{array}{l}.118^{* *} \\
(.0502)\end{array}$ & $\begin{array}{l}.0135 \\
(.0455)\end{array}$ & $\begin{array}{c}.0135^{*} \\
(.00693)\end{array}$ & $\begin{array}{l}.0281 * * * \\
(.00755)\end{array}$ & $\begin{array}{l}.0207 * * * \\
(.00684)\end{array}$ \\
\hline CONTROLS & {$[\mathrm{mv}]$} & {$[\mathrm{mv}]$} & {$[\mathrm{mv}]$} & {$[\mathrm{mv}]$} & {$[\mathrm{mv}]$} & {$[\mathrm{mv}]$} \\
\hline$N$ & 153 & 254 & 255 & 153 & 254 & 255 \\
\hline
\end{tabular}

Notes: Standard errors in parentheses. $* p<0.1, * * p<0.05, * * * p<0.01$. ASVOTE ${ }^{19 C}$ is the average vote for anti-Semitic parties between 1890 and 1912. NSVOTE ${ }^{20 s}$ is the average vote for the Nazi party in the 1920s (DVFP in 1924 and NSDAP in 1928). NSVOTE ${ }^{30 s}$ is the average vote for the Nazi party in the 1930s (elections in September 1930 and March 1933). CONTROLS comprise the city-level averages of all control variables used in Table 5. All regressions use the number of subjects in the survey for each city as analytical weights. Panel B reports Poisson Maximum Likelihood estimation results. Panels C and D report results from propensity score matching, based on above- and below-median values of the corresponding AS Variable. Average treatment effects for the treated are reported. In Panel C, geographic longitude and latitude are used as matching variables in addition to the variables denoted by CONTROLS. 


\section{Appendix}

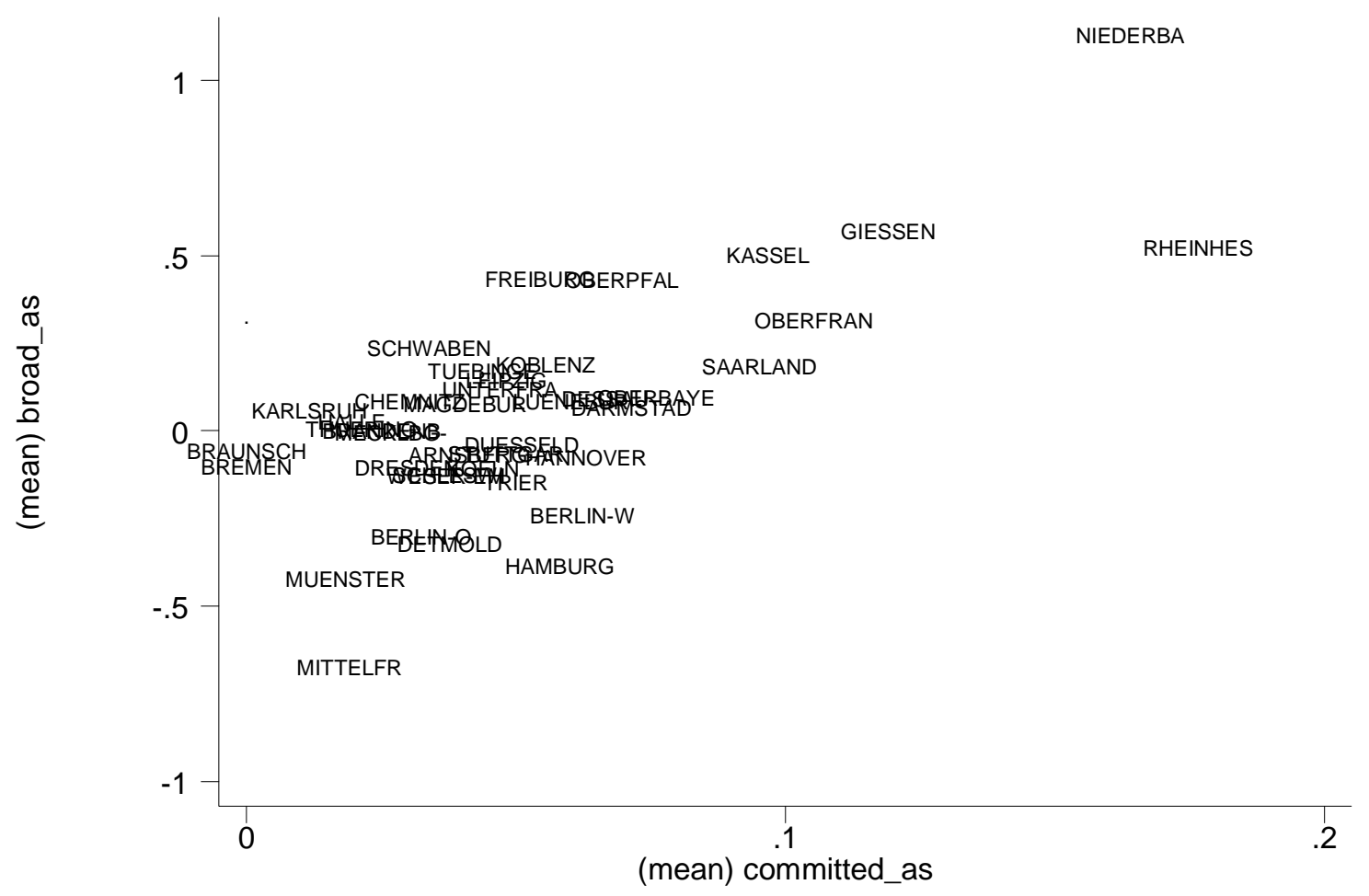

Figure A.1: The relationship between broad anti-Semitism and the share of committed antiSemites 


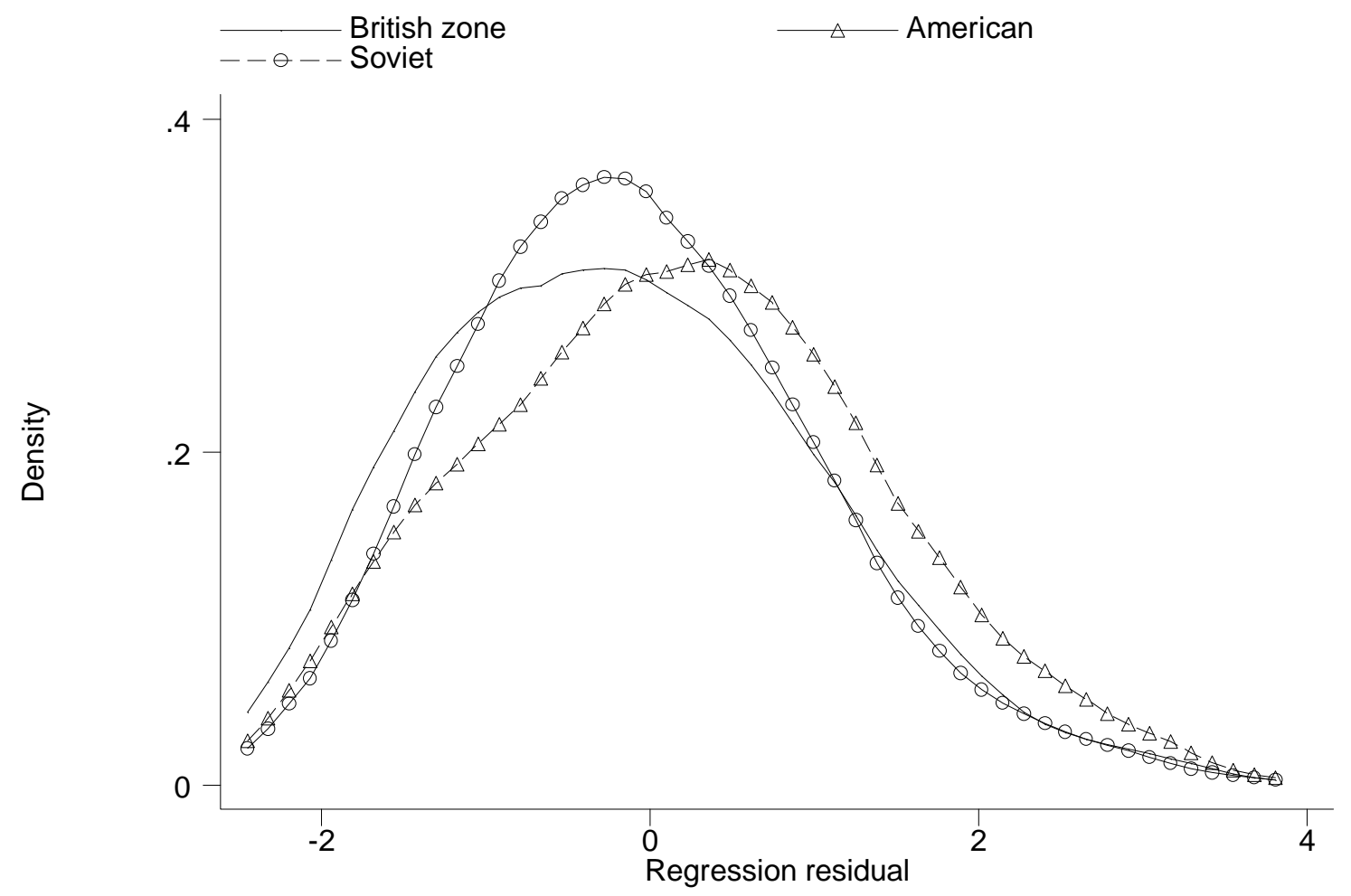

Figure A.2: Anti-Semitism in the former British, American, and Soviet zones [residual after controlling for historical levels of anti-Semitism by regressing broad anti-Semitism today on ALLVOTE] 